\title{
Macrophages regulate gastrointestinal motility through complement component 1q
}

Mihir Pendse ${ }^{1}$, Yun Li $^{1}$, Cristine N. Salinas ${ }^{1}$, Gabriella Quinn ${ }^{1}$, Nguyen Vo ${ }^{1}$, Daniel C. Propheter ${ }^{1}$,

Chaitanya Dende ${ }^{1}$, Alexander A. Crofts ${ }^{1}$, Eugene Koo $^{1}$, Brian Hassell ${ }^{1}$, Kelly A. Ruhn ${ }^{1}$, Prithvi Raj ${ }^{1}$, Yuuki Obata $^{1 *}$, Lora V. Hooper ${ }^{1,2^{*}}$

${ }^{1}$ Department of Immunology, The University of Texas Southwestern Medical Center, Dallas, TX 75390

${ }^{2}$ The Howard Hughes Medical Institute, The University of Texas Southwestern Medical Center, Dallas, TX 75390

*For correspondence: yuuki.obata@utsouthwestern (YO), lora.hooper@utsouthwestern.edu (LVH) 


\section{ABSTRACT}

Peristaltic movement of the intestine propels food down the length of the gastrointestinal tract to promote nutrient absorption. Interactions between intestinal macrophages and the enteric nervous system regulate gastrointestinal motility, yet we have an incomplete understanding of the molecular mediators of this crosstalk. Here we identify complement component $1 \mathrm{q}(\mathrm{C} 1 \mathrm{q})$ as a macrophage product that regulates gut motility. Macrophages were the predominant source of $\mathrm{C} 1 \mathrm{q}$ in the mouse intestine and most extraintestinal tissues. Although C1q mediates complement-mediated killing of bacteria in the bloodstream, we found that C1q was not essential for immune defense of the intestine. Instead, C1q-expressing macrophages were localized to the intestinal submucosal plexus where they were closely associated with enteric neurons and expressed surface markers characteristic of nerve-adjacent macrophages in other tissues. Mice with a macrophage-specific deletion of Clqa showed changes in enteric neuronal gene expression, increased peristaltic activity, and accelerated intestinal transit. Our findings identify C1q as a key regulator of gastrointestinal motility and provide enhanced insight into the crosstalk between macrophages and the enteric nervous system.

\section{INTRODUCTION}

Peristalsis is the physical force that propels food through the intestine, promoting digestion and nutrient absorption. The gastrointestinal motility that underlies peristalsis is a complex process that requires coordination of the activity of smooth muscle cells by enteric neurons (Rao and Gershon, 2016). Recent

21 studies have revealed that intestinal macrophages impact gastrointestinal motility by regulating the

22 functions of enteric neurons and facilitating their interactions with smooth muscle cells ( Muller et al., 2014;

23 Matheis et al., 2020).

Macrophages carry out diverse functions in the intestine that vary according to their anatomic

25 location. For example, macrophages that localize to the tissue located directly underneath the gut

26 epithelium - known as the lamina propria — contribute to immune defense against pathogenic bacteria 
(Gabanyi et al., 2016). A distinct group of macrophages localizes to the tissues located beneath the lamina propria, between the circular and longitudinal muscle layers in the tissue region known as the muscularis externa. These muscularis macrophages express genes that are distinct from lamina propria macrophages (Gabanyi et al., 2016). They directly regulate the activity of smooth muscle cells (Luo et al., 2018) and secrete soluble factors such as bone morphogenetic protein 2 (BMP2) that interact with the enteric neurons that control smooth muscle activity (Muller et al., 2014). Muscularis macrophages thus play a key role in regulating gut motility. However, our understanding of the molecular mechanisms by which these macrophages regulate intestinal neuromuscular activity and gut motility remains limited.

$\mathrm{C} 1 \mathrm{q}$ is a member of the defense collagen family that has distinct functions in immune defense and nervous system development and function (Bossi et al., 2014; Casals et al., 2019; Shah et al., 2015; Thielens et al., 2017). C1q is composed of six molecules each of $\mathrm{C} 1 \mathrm{qA}, \mathrm{C} 1 \mathrm{qB}$, and $\mathrm{C} 1 \mathrm{qC}$, forming a $410 \mathrm{kDa}$ oligomer. C1q circulates in the bloodstream, where it participates in immune defense against infection by recognizing antibodies bound to invading bacteria. This binding interaction initiates the classical complement pathway, which entails the recruitment and proteolytic processing of other complement components that rupture the bacterial membrane and recruit phagocytic cells (Kishore and Reid, 2000; Noris and Remuzzi, 2013). C1q is also produced by microglia (brain-resident macrophage-like cells) in the brain where it promotes the pruning of neuronal synapses through an unclear mechanism (Hammond et al., 2020; Hong et al., 2016). Consequently, C1q deficiency results in heightened synaptic connectivity in the central nervous system that can lead to epilepsy (Chu et al., 2010). pathogenic microbes are frequent. However, little is known about the physiological role of $\mathrm{C} 1 \mathrm{q}$ in barrier tissues. Liver immune cells, including macrophages and dendritic cells, produce serum C1q; however the cellular source of $\mathrm{Clq}$ in barrier tissues including the intestine remains unclear (Petry et al., 2001). Here, we show that $\mathrm{C} 1 \mathrm{q}$ is selectively produced by macrophages that inhabit the submucosal plexus of the mouse

51 intestine. These C1q-expressing macrophages are located close to enteric neurons that have a known role 52 in controlling gut motility. Consistent with their nerve-adjacent localization, mice lacking macrophage C1q 
exhibit altered expression of enteric neuronal genes, increased peristaltic activity, and accelerated gastrointestinal motility. These findings identify $\mathrm{Clq}$ as a key mediator of a neuroimmune interaction that regulates gut motility.

\section{RESULTS}

\section{C1q is expressed in intestinal macrophages}

Soluble defense collagens are an ancient, evolutionarily conserved family of antimicrobial proteins with shared structural features including a $C$-terminal globular head and a collagen-like region (Casals et al., 2019). Little is known about the function of defense collagens at mucosal barrier sites, where microbial encounter is frequent. Our initial goal in this study was to identify soluble defense collagens that are expressed by the mouse intestine and to assess their role in host defense. We therefore measured the expression of 18 defense collagen genes in the mouse small intestine and colon by RNA sequencing (RNAseq). This analysis revealed that the most abundant soluble defense collagen transcripts in the small intestine and colon were those encoding $\mathrm{C} 1 \mathrm{qA}, \mathrm{C} 1 \mathrm{qB}$, and $\mathrm{C} 1 \mathrm{qC}$ (Figure 1A; Figure 1-figure supplement 1).

Serum C1q is produced by liver dendritic cells, monocytes, and macrophages (El-Shamy et al., 2018). However, the cellular source(s) of C1q in peripheral tissues including the intestine is unknown. Quantitative PCR (qPCR) analysis of fluorescence-activated cell sorting (FACS)-sorted cell suspensions recovered from the small intestines of wild-type C57BL/6 mice revealed that Clqa, C1qb, and Clqc transcripts were most abundant in $\mathrm{CD} 45^{+}$cells, which include all immune cells, as compared to $\mathrm{CD} 45^{-}$cells, which encompass non-immune cells such as epithelial cells (Figure 1B). Further, C1q transcripts and protein were most abundant in $\mathrm{CD} 45^{+}$cells recovered from the subepithelial compartment, which includes both the lamina propria and muscularis, as compared to $\mathrm{CD} 5^{+}$cells recovered from the intraepithelial compartment of the small intestine (Figure $1 C$ and D). Thus, $\mathrm{C} 1 \mathrm{q}$ is expressed by immune cells located in the subepithelial compartment of the intestine and is largely absent from epithelial cells and intraepithelial 78 immune cells. 
To identify the intestinal immune cell population that expresses C1q, we further analyzed the

$$
\text { subepithelial } \mathrm{CD} 45^{+} \text {cell population by flow cytometry. Expression of C1q transcripts and protein was }
$$

highest in $\mathrm{CD}_{11} \mathrm{~b}^{+} \mathrm{MHCII}{ }^{+} \mathrm{F} 4 / 80^{\text {hi }}$ macrophages and was mostly absent from all non-macrophage immune

$$
\text { cells (Figure } 1 \boldsymbol{E}-\boldsymbol{H}) \text {. Thus, C1q is expressed by macrophages in the mouse small intestine. }
$$
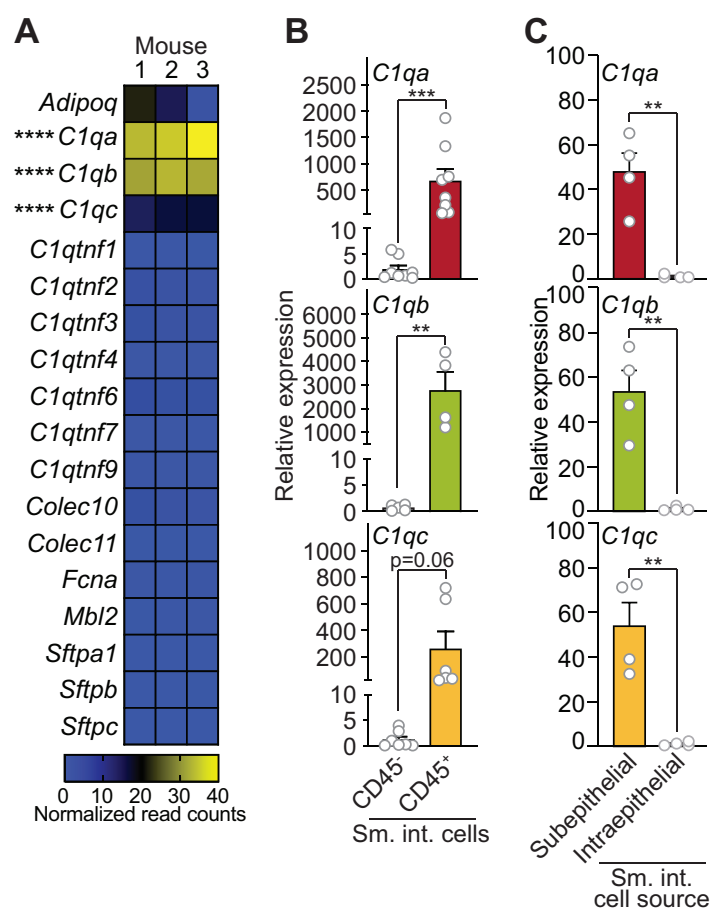

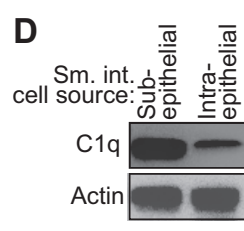

E
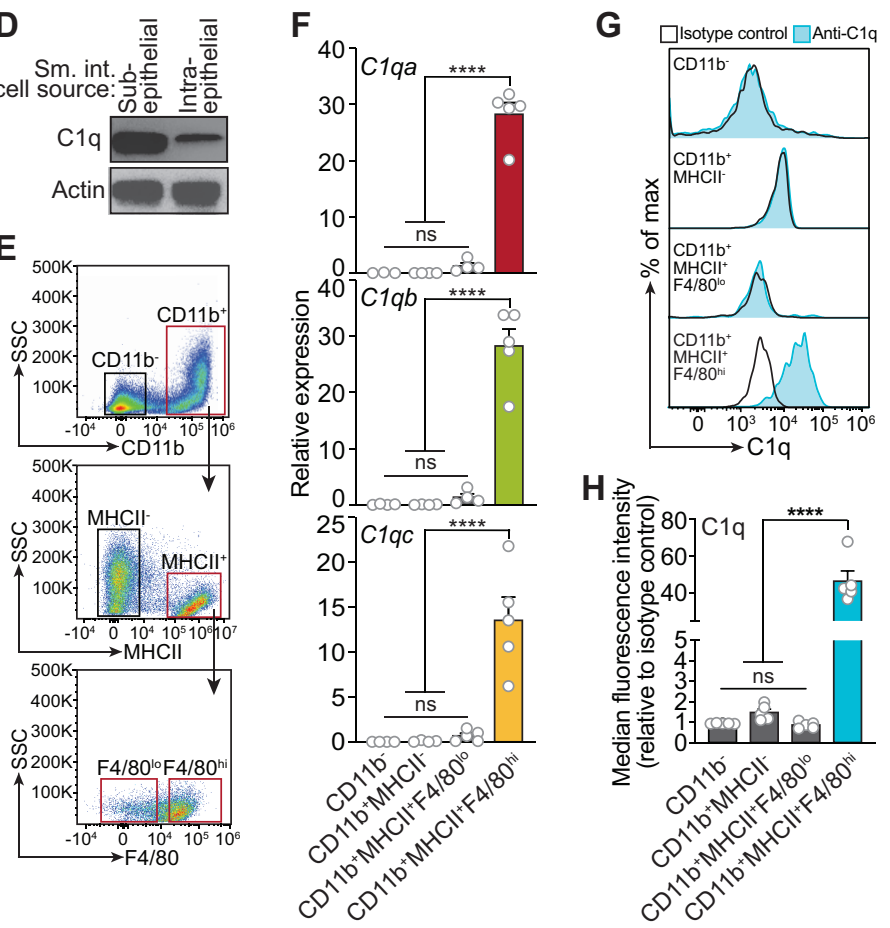

Figure 1. C1q is expressed by macrophages in the mouse small intestine.

(A) RNA-seq analysis of soluble defense collagen expression in the small intestines (ileum) of C57BL/6 mice. Data were adapted from a previously published RNA-seq analysis (Gattu et al., 2019). Data are available in the Gene Expression Omnibus repository under accession number GSE122471. Each column represents one mouse.

(B) qPCR measurement of $C l q a, C l q b$, and $C l q c$ transcript abundance in $\mathrm{CD}^{2} 5^{+}$and $\mathrm{CD} 45^{-}$cells purified from mouse small intestines by flow cytometry. Each data point represents one mouse, and results are representative of two independent experiments.

(C) qPCR measurement of Clqa, Clqb, and Clqc transcript abundance in subepithelial and intraepithelial cells recovered from mouse small intestines. Each data point represents one mouse, and results are representative of three independent experiments.

(D) Representative immunoblot of subepithelial and intraepithelial cells recovered from mouse small intestines, with detection of $\mathrm{Clq}$ and actin (control). Each lane represents cells from one mouse and immunoblot is representative of three independent experiments.

(E) Flow cytometry gating strategy for analysis of mouse small intestinal cell suspensions in panels F, G, and H. Cells were pre-gated as live $\mathrm{CD} 45^{+}$cells. SSC, side-scatter; MHCII, major histocompatibility complex II.

(F) qPCR measurement of $C l q a, C l q b$, and $C l q c$ transcript abundance in cells isolated by flow cytometry from mouse small intestines as indicated in (E). Each data point represents cells pooled from three mice, and results are representative of three independent experiments.

(G) Flow cytometry analysis of intracellular C1q in small intestinal subepithelial cells identified as indicated in (E).

(H) Quantitation of flow cytometry analysis in $(\mathrm{G})$. Each data point represents one mouse, and results are representative of two independent experiments. 
Sm. int., mouse small intestine; Error bars represent SEM. ${ }^{* *} \mathrm{p}<0.01 ;{ }^{* * *} \mathrm{p}<0.001 ;{ }^{* * * *} \mathrm{p}<0.0001$; ns, not significant by one way ANOVA (A,F) or two-tailed Student's t-test (B,C,H).

Figure supplement 1. C1q is expressed in the mouse colon.

\section{Macrophages are the primary source of $\mathrm{C} 1 \mathrm{q}$ in the mouse gastrointestinal tract}

We next assessed whether macrophages are the primary source of $\mathrm{Clq}$ in the intestine by analyzing two mouse models. First, we depleted macrophages by injecting neutralizing antibodies directed against the receptor for colony stimulating factor $1(\mathrm{CSF} 1 \mathrm{R})($ Figure $2 A)$, which is required for the development of a subset of lamina propria macrophages (Bogunovic et al., 2009) and all muscularis macrophages (Muller et al., 2014). Antibody injection led to a $>2$-fold reduction in the number of macrophages recovered from the small intestine (Figure $2 B$ ), and a corresponding $>2$-fold reduction in small intestinal C1q gene expression (Figure 2 C), suggesting that macrophages are the primary source of intestinal C1q.

Second, we constructed a genetic model of C1q deficiency by crossing $C 1 q a^{\mathrm{fl} / \mathrm{fl}}$ mice (Fonseca et al., 2017) to mice carrying the Lyz2-Cre transgene (LysM-Cre mice), which is selectively expressed in myeloid cells including macrophages (Figure 2D). These mice, hereafter designated as $C 1 q a^{\Delta \mathrm{M} \phi}$ mice, lacked C1q expression in intestinal macrophages (Figure $2 \boldsymbol{E}$ and $\boldsymbol{F}$ ). Importantly, Clqa ${ }^{\Delta \mathrm{M} \phi}$ mice had markedly lower overall C1q expression in both the small intestine and colon (Figure 2G), indicating that macrophages are the main source of $\mathrm{Clq}$ in the intestine. Unexpectedly, the $C l q a^{\Delta \mathrm{M} \phi}$ mice also lost $C 1 q$ gene expression in the lung, skin, kidney, and liver (but not the brain), and C1q protein was undetectable in the serum (Figure 2 - figure supplement 1). These findings indicate that macrophages are the primary source of $\mathrm{Clq}$ in the intestine and suggest that $\mathrm{LysM}^{+}$macrophages or macrophage-like cells are also the main source of $\mathrm{Clq}$ in most extraintestinal tissues and the bloodstream. 

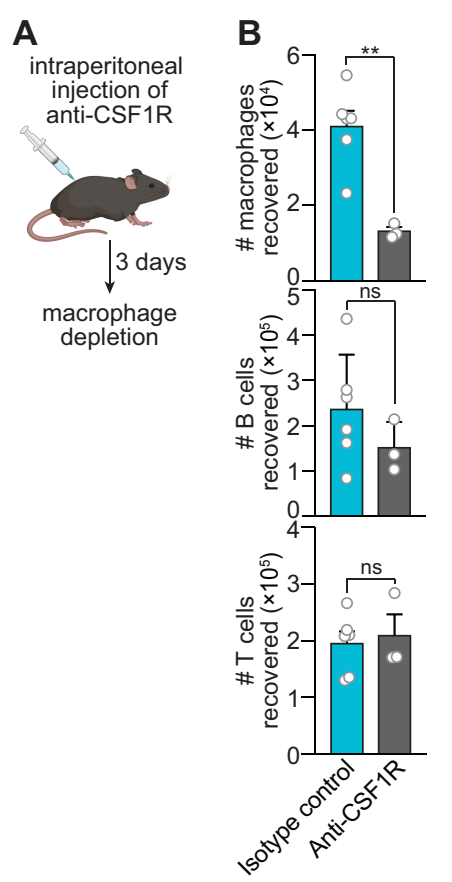

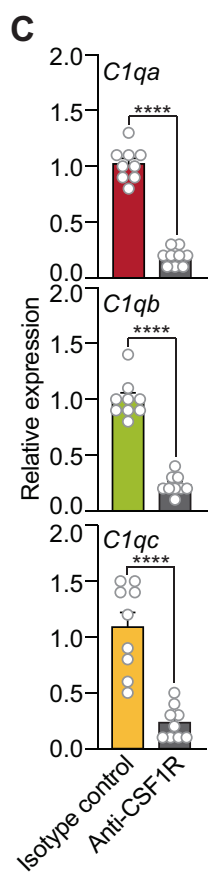

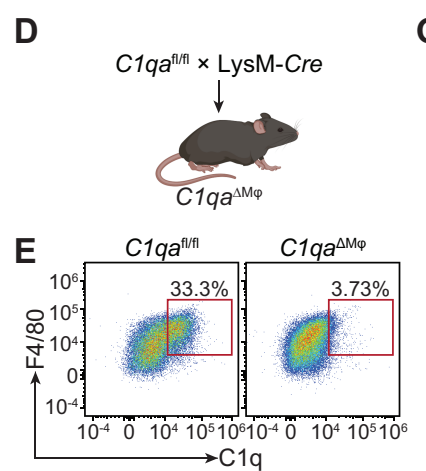
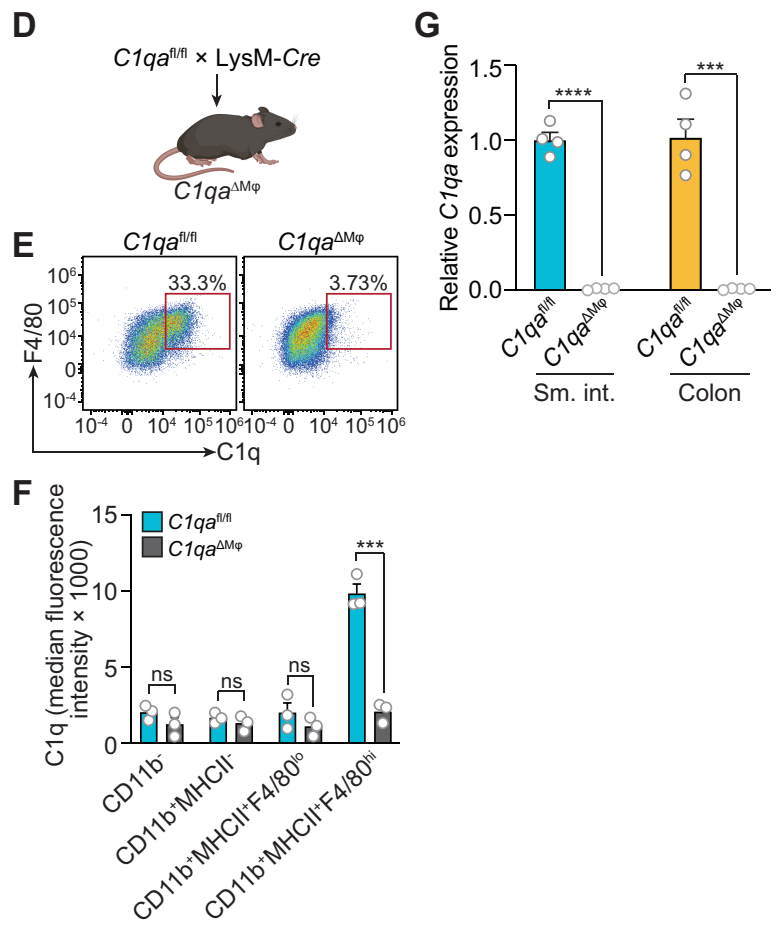

Figure 2. Macrophages are the primary source of $\mathrm{C1q}$ in the mouse gastrointestinal tract.

(A) Graphic showing selective depletion of macrophages in C57BL/6 mice by intraperitoneal injection of anti-CSF1R antibody. Control mice were injected with isotype-matched non-specific antibody. Mice were analyzed 72 hours after antibody injection. Panel was generated at Biorender.com.

(B) Representative flow cytometry analysis of mouse small intestines after intraperitoneal injection of anti-CSF1R or isotype control antibody. All cells were gated as live $\mathrm{CD}^{2} 5^{+}$. Macrophages were $\mathrm{MHCII}^{+} \mathrm{F} 4 / 80^{\mathrm{hi}}$; $\mathrm{B}$ cells were $\mathrm{CD} 19^{+}$; $\mathrm{T}$ cells were $\mathrm{CD}^{+}$. Total small intestinal cell yields were $1.5 \times 10^{6} \pm 4.9 \times 10^{5}$ cells.

(C) qPCR measurement of Clqa, Clqb, and Clqc transcript abundance in mouse small intestines after intraperitoneal injection of anti-CSF1R or rat IgG2a (isotype control). Each data point represents one mouse and results are pooled from two independent experiments.

(D) $C l q a^{\mathrm{fl} / \mathrm{fl}}$ mice were crossed with mice harboring a LysM-Cre transgene to generate mice having a macrophageselective deletion of $C l q a\left(C l q a^{\Delta \mathrm{M} \varphi}\right.$ mice). Panel was generated at Biorender.com.

(E) Representative flow cytometry analysis of intracellular C1q expression in small intestinal macrophages from $C l q a^{\mathrm{fl} / \mathrm{fl}}$ and $C l q a^{\Delta \mathrm{M} \varphi}$ mice. Mice were littermates from heterozygous crosses that remained co-housed. Cells were gated on live $\mathrm{CD}^{2} 5^{+} \mathrm{CD} 11 \mathrm{~b}^{+} \mathrm{MHCII}^{+}$.

(F) Quantitation of the flow cytometry analysis in (E). Each data point represents one mouse. Results are representative of two independent experiments.

(G) qPCR measurement of Clqa transcript abundance in the small intestines (sm. int.) and colons of $C l q a^{\mathrm{fl} / \mathrm{fl}}$ and $C l q a^{\Delta \mathrm{M} \varphi}$ littermates. Each data point represents one mouse.

Error bars represent SEM. ${ }^{* *} \mathrm{p}<0.01 ;{ }^{* *} \mathrm{p}<0.001 ; * * * * \mathrm{p}<0.0001$; ns, not significant by two-tailed Student's t-test.

Figure supplement 1. C1q expression is lost systemically but preserved in the central nervous system of $C 1 q a^{\Delta \mathrm{M} \varphi}$ mice. 
infection

The classical complement pathway is a well-studied host defense system that protects against systemic pathogenic infection (Warren et al., 2002; Noris and Remuzzi, 2013). Circulating C1q activates the complement pathway by binding to antibody-antigen complexes or to bacterial cell surface molecules, and thus protects against systemic infection. We therefore assessed whether C1q promotes immune defense of the intestine.

We first determined whether $\mathrm{C} 1 \mathrm{q}$ exhibits characteristics of known intestinal antimicrobial not detected in the gut lumen of either conventional or germ-free mice (Figure 3B). Clqa expression was

172 also not markedly altered by oral infection with the intestinal pathogenic bacterial species Salmonella

173 Typhimurium (Figure 3 C). These data indicate that $\mathrm{C} 1 \mathrm{q}$ is not induced by the gut microbiota or by the 174 bacterial pathogen $S$. Typhimurium, in contrast to other antibacterial proteins.

175 We next assessed whether C1q regulates the composition of the gut microbiota. 16S rRNA gene 176 sequencing analysis of the fecal microbiotas of $C 1 q a^{\mathrm{fl} / \mathrm{fl}}$ and $C 1 q a^{\Delta \mathrm{M \phi}}$ mice showed that the microbiota 177 composition was not appreciably altered in the absence of macrophage C1q (Figure 3D). We also 178 challenged $C 1 q a^{\mathrm{fl} / \mathrm{fl}}$ and $C 1 q a^{\Delta \mathrm{M} \phi}$ mice with dextran sulfate sodium (DSS), which damages the colonic 179 epithelium and exposes underlying tissues to the commensal microbiota. However, the sensitivity of the $180 C l q a^{\Delta \mathrm{M \phi}}$ mice to DSS was similar to that of their $C 1 q a^{\mathrm{fl} / \mathrm{fl}}$ littermates as assessed by change in body weight

181 (Figure 3E). There was also no change in intestinal paracellular permeability in $C 1 q a^{\Delta \mathrm{M} \phi}$ mice as measured 
182

183

184

185

186

187

188

189

190

191

192

by oral administration of FITC-dextran (Figure 3F). These results suggest that macrophage C1q does not substantially impact gut microbiota composition or intestinal epithelial barrier function.

To determine whether $\mathrm{Clq}$ protects against enteric infection we conducted oral infection experiments with the enteric pathogen Citrobacter rodentium. We chose $C$. rodentium as our model organism for two reasons. First, $C$. rodentium is a non-disseminating pathogen, allowing us to test specifically for C1q's role in intestinal infection. Second, C. rodentium clearance depends on immunoglobulins and complement component C3 (Belzer et al., 2011). Because C1q is bactericidal in concert with $\mathrm{C} 3$ and immunoglobulins, we predicted that $C 1 q a^{\Delta \mathrm{M} \phi}$ mice would show enhanced susceptibility to $C$. rodentium infection. However, $C 1 q a^{\Delta \mathrm{M} \phi}$ mice cleared $C$. rodentium similarly to their $C 1 q a^{\mathrm{fl} / \mathrm{fl}}$ littermates, indicating that $\mathrm{C} 1 \mathrm{q}$ is dispensable for defense against $C$. rodentium infection (Figure $3 G)$.

We also did not observe marked alterations in immunity in the absence of C1q. Comparison of cytokine transcript abundance in the small intestines of $C l q a^{\mathrm{fl} / \mathrm{fl}}$ and $C l q a^{\Delta \mathrm{M} \phi}$ littermates revealed no statistically significant differences in cytokine expression (Figure $3 \boldsymbol{H}$ ). There were also no statistically significant differences in the percentages or absolute numbers of various $\mathrm{T}$ cell subsets, including $\mathrm{T}_{\text {helper }} 1$ $\left(\mathrm{T}_{\mathrm{H}} 1\right), \mathrm{T}_{\mathrm{H}} 2, \mathrm{~T}_{\mathrm{H}} 17$, and regulatory $\mathrm{T}\left(\mathrm{T}_{\mathrm{reg}}\right)$ cells between $C 1 q a^{\mathrm{fl} / \mathrm{fl}}$ and $C 1 q a^{\Delta \mathrm{M} \phi}$ mice (Figure 3I; Figure 3 figure supplement 1). Although total B cell numbers trended lower in Clqa ${ }^{\Delta \mathrm{M \phi}}$ mice, the difference was not statistically significant (Figure 3I; Figure 3 - figure supplement 2). There were also no statistically significant differences in the percentages or absolute numbers of total plasma cells (Figure 3I; Figure 3 figure supplement 2), IgA $\mathrm{A}^{+}$plasma cells (Figure 3I; Figure 3 - figure supplement 2), myeloid cells (Figure 3I; Figure 3 - figure supplement 3), or innate lymphoid cells (Figure 3I; Figure 3 - figure supplement 4) when comparing $C 1 q a^{\mathrm{fl} / \mathrm{fl}}$ and $C 1 q a^{\Delta \mathrm{M} \phi}$ mice. These results suggest that the absence of macrophage $\mathrm{C} 1 \mathrm{q}$ has little impact on intestinal immunity. Altogether, our findings suggest that $\mathrm{C} 1 \mathrm{q}$ does not participate substantially in intestinal immune defense and thus might have an intestinal function that is independent of its canonical role in activating the classical complement pathway. 
A
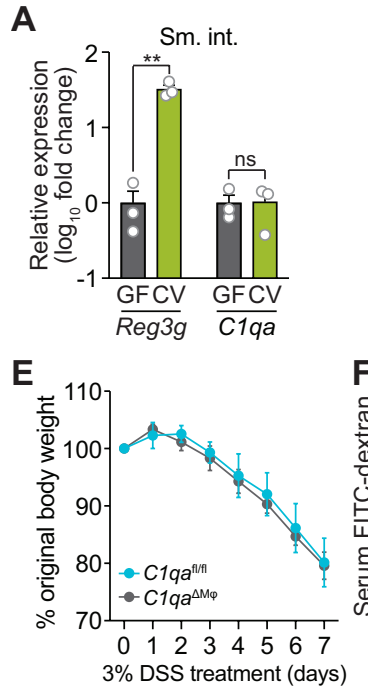

I

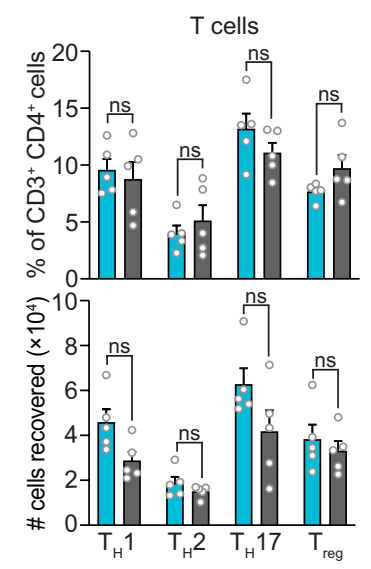

B
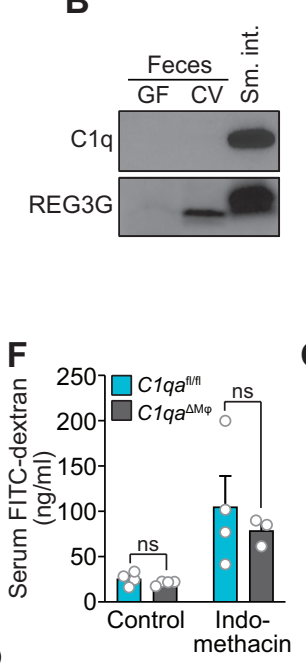

C
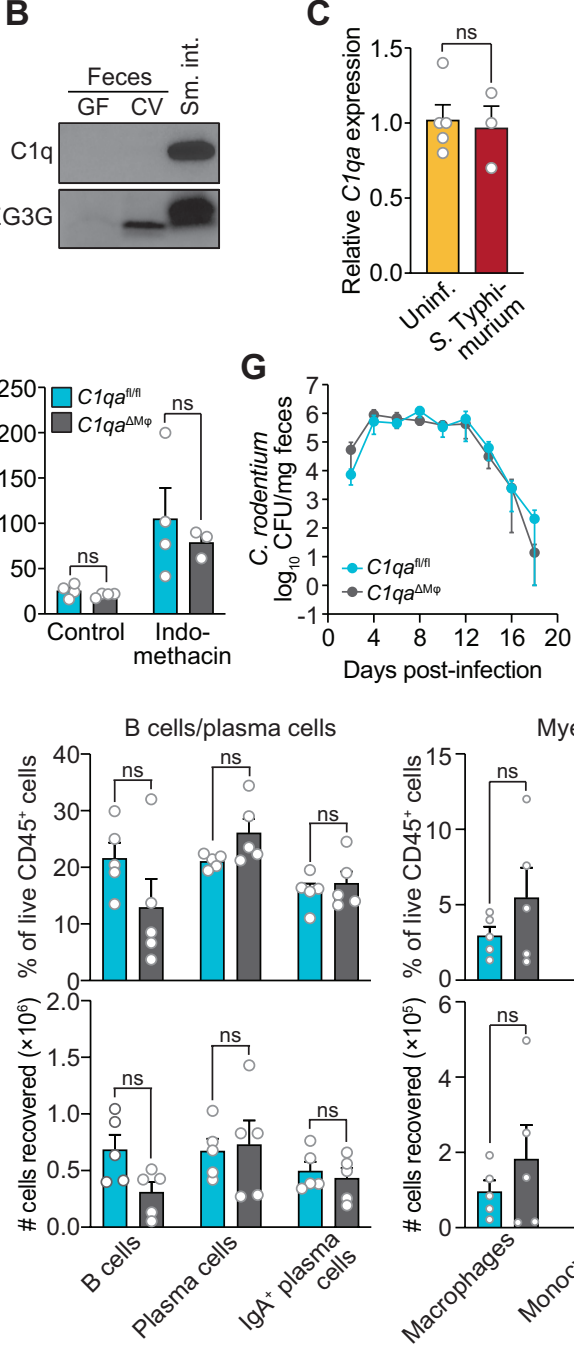
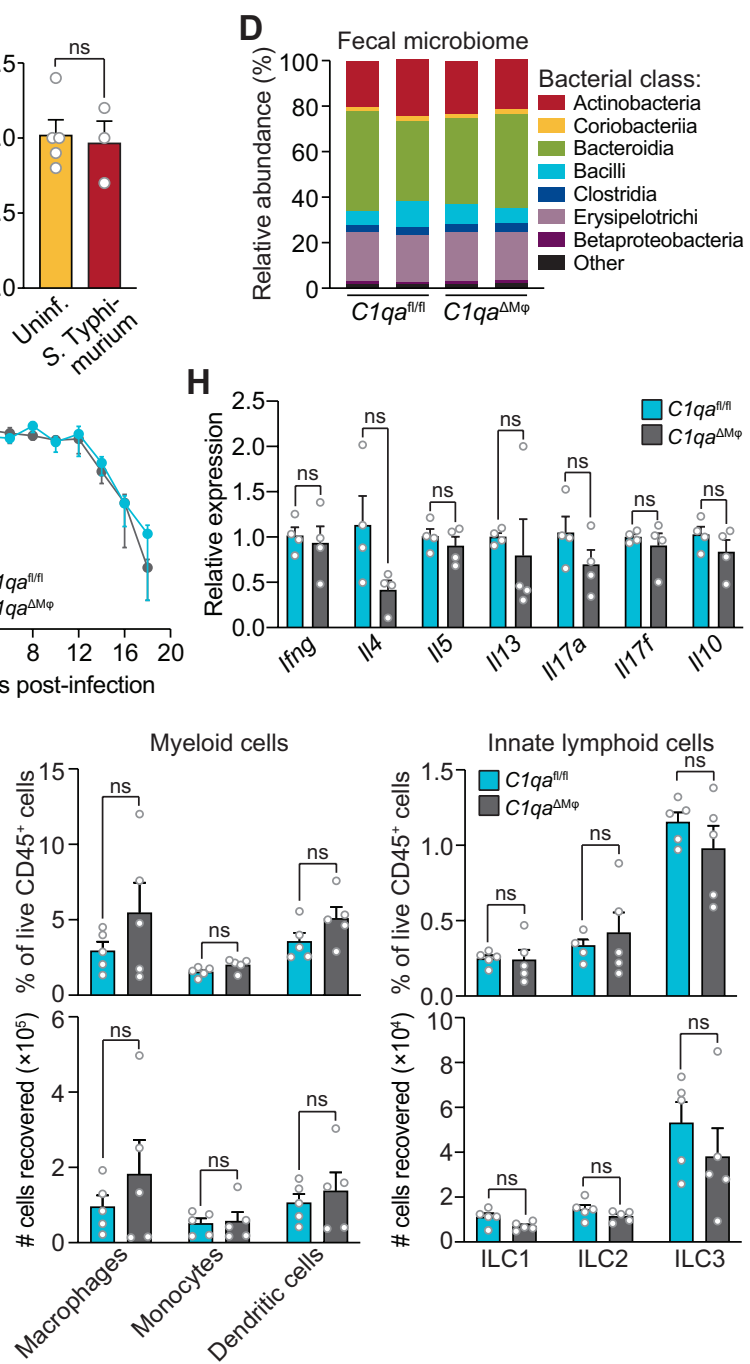

Figure 3. $\mathrm{Clqa}^{\mathrm{\Lambda M \varphi}}$ mice do not show altered microbiota composition, barrier function, or resistance to enteric infection.

(A) Small intestinal Clqa expression is not induced by the intestinal microbiota. qPCR measurement of Reg3g and Clqa transcript abundances in the small intestines of germ free (GF) and conventional (CV) C57BL/6 mice. Each data point represents one mouse and results are representative of two independent experiments.

(B) $\mathrm{Clq}$ is not detected in the mouse intestinal lumen or feces. Representative immunoblot of an ammonium sulfate precipitation of intestinal lumenal contents and feces from germ-free and conventional mice with detection of C1q. $\mathrm{Clq}$ in small intestinal tissue (sm. int.) is shown for comparison at right. REG3G was detected as a control, as it is secreted into the intestinal lumen of conventional mice (Cash et al., 2006). Each lane represents multiple mice pooled ( $\mathrm{n}=5$ and 9 for germ-free and conventional, respectively) and the immunoblot is representative of three independent experiments.

(C) C1q gene expression is not altered by enteric infection with $S$. Typhimurium. qPCR measurement of $C$ lqa transcript abundance in small intestinal tissue after oral inoculation of mice with $10^{9}$ colony forming units of $S$. experiments.

(D) Intestinal microbiota composition is not altered in $C 1 q a^{\Delta \mathrm{M} \varphi}$ mice. Phylogenetic analysis of $16 S$ rRNA gene sequences from fecal pellets collected from Clqa ${ }^{\mathrm{fl} / \mathrm{fl}}$ and $\mathrm{Cl}_{\mathrm{q}} a^{\Delta \mathrm{M} \varphi}$ littermates. Operational taxonomic units with an 
average of 100 reads and populations greater than or equal to $1 \%$ were included in the graphical analysis. Each bar represents one mouse. Data are available from the Sequence Read Archive under BioProject ID PRJNA793870.

(E) $C l q a^{\Delta \mathrm{M} \varphi}$ mice do not show altered susceptibility to dextran sulfate sodium (DSS)-induced colitis. Mice were provided with $3 \%$ DSS in drinking water and body weights were monitored for 7 days. $\mathrm{n}=4$ and 6 for $C l q a^{\mathrm{fl} / \mathrm{fl}}$ and $C 1 q a^{\Delta \mathrm{M} \varphi}$ littermates, respectively. Error bars represent SEM. Differences at each time point were not significant by two-tailed Student's t-test.

(F) $C 1 q a^{\Delta \mathrm{M} \varphi}$ mice do not show altered intestinal permeability. To measure intestinal permeability, $C 1 q a^{\mathrm{f} / \mathrm{fl}}$ and Clqa ${ }^{\Delta \mathrm{M} \varphi}$ littermates were gavaged with FITC-dextran, and serum FITC-dextran levels were determined by fluorescence microplate assay against a FITC-dextran standard curve. Indomethacin induces intestinal damage in mice and was used as a positive control.

(G) Time course of fecal $C$. rodentium burden following oral gavage of $C 1 q a^{\mathrm{fl} / \mathrm{fl}}$ and $C 1 q a^{\Delta \mathrm{M} \varphi}$ mice with $5 \times 10^{8}$ colony forming units $(\mathrm{CFU})$ of $C$. rodentium. $\mathrm{n}=5$ and 5 for $C l q a^{\mathrm{fl} / \mathrm{fl}}$ and ${ }^{\mathrm{Cl} \text { lq } \Delta \mathrm{M} \varphi}$ littermates, respectively. Error bars represent SEM. Differences at each time point were not significant by two-tailed Student's t-test.

(H) qPCR measurement of cytokine transcript abundances in the small intestines of $C l q a^{\mathrm{fl} / \mathrm{fl}}$ and $C$ lq $a^{\Delta \mathrm{M} \varphi}$ littermates. Error bars represent SEM. Statistics were performed with two-tailed Student's t-test.

(I) Flow cytometry analysis of small intestinal immune cell subsets from $C 1 q a^{\mathrm{fl} / \mathrm{fl}}$ and $C 1 q a^{\Delta \mathrm{M} \varphi}$ littermates. Gating strategies are shown in Figure 3 - figure supplement 1 through 4. ILC, innate lymphoid cell. Total small intestinal cell yields were $8.8 \times 10^{6} \pm 2.9 \times 10^{6}$ cells.

Error bars represent SEM. ${ }^{* *} \mathrm{p}<0.01 ; \mathrm{ns}$, not significant by two-tailed Student's t-test.

Figure supplement 1. Flow cytometry gating strategy for comparison of T cell populations in $C 1 q a^{\mathrm{fl} / \mathrm{fl}}$ and $C 1 q a^{\Delta \mathrm{M} \varphi}$ mice.

Figure supplement 2. Flow cytometry gating strategy for comparison of B cell and plasma cell populations in $C 1 q a^{\mathrm{fl} / \mathrm{fl}}$ and $C l q a^{\Delta \mathrm{M} \varphi}$ mice.

Figure supplement 3. Flow cytometry gating strategy for comparison of myeloid cell populations in $C l q a^{\mathrm{f} / / f l}$ and Clqa $a^{\Delta \mathrm{M} \varphi}$ mice.

Figure supplement 4. Flow cytometry gating strategy for comparison of innate lymphoid cell populations in $C 1 q a^{\mathrm{fl} / \mathrm{fl}}$ and $C l q a^{\Delta \mathrm{M \varphi}}$ mice.

\section{C1q-expressing gut macrophages are located near enteric neurons}

Intestinal macrophages perform distinct functions depending on their anatomical location.

Macrophages in the lamina propria protect against invasion by pathogenic microbes and promote tissue repair (Grainger et al., 2017). In contrast, macrophages that reside in deeper intestinal tissues, including the submucosal plexus and muscularis (Figure 4A), regulate enteric smooth muscle cells and neurons that drive gastrointestinal motility (De Schepper, Stakenborg, et al., 2018; De Schepper, Verheijden, et al., 2018).

Immunofluorescence analysis revealed that $\mathrm{C} 1 \mathrm{q}$ was located primarily beneath the lamina propria, in a region consistent with the location of the submucosal plexus of the small intestine and colon (Figure $4 \boldsymbol{A}$ and $\boldsymbol{B}) . \mathrm{C} 1 \mathrm{q}$ was detected in a diffuse pattern close to macrophages in $C 1 q a^{\mathrm{fl} / \mathrm{fl}}$ mice and was absent in $C 1 q a^{\Delta \mathrm{M} \phi}$ mice (Figure $4 \boldsymbol{B}$ ) despite the presence of similar overall numbers of $\mathrm{CD} 169^{+}$macrophages 
(Figure 4-figure supplement 1). Although we did not observe direct colocalization of C1q with CD169, a macrophage marker that selectively marks nerve-adjacent macrophages (Ural et al., 2020), the pattern was consistent with prior observations of $\mathrm{C} 1 \mathrm{q}$ deposition in the extracellular matrix in the arterial wall (Cao et al., 2003)(Figure 4 B).

We next assessed the location of $\mathrm{C} 1 \mathrm{q}$ relative to enteric neurons in the mouse small intestine. Detection of the neuronal marker $\beta$ III tubulin (TUBB3) revealed the presence of two distinct layers of enteric neurons: one just beneath the lamina propria that was consistent with the location of the submucosal plexus, and one in the muscularis that was consistent with the location of the myenteric plexus (Figure 4C). in the submucosal plexus. macrophages in other tissues. First, prior studies have shown that microglia in the central nervous system

282 and nerve-adjacent macrophages in peripheral tissues, such as the lung, are enriched for C1q gene 283 expression (Fonseca et al., 2017; Ural et al., 2020). This is consistent with our observations of C1q 284 expression in nerve-adjacent intestinal macrophages located in the submucosal plexus (Figure 4C). Second, 285 nerve-adjacent macrophages depend on a CSF1-CSF1R signaling axis for their maintenance and are therefore sensitive to anti-CSF1R antibody-mediated depletion (Muller et al., 2014). Thus, our finding that anti-CSF1R administration depleted C1q-expressing intestinal macrophages is consistent with their location near enteric neurons (Figure $2 \boldsymbol{A}-\boldsymbol{C}$ ). Third, C1q-expressing intestinal macrophages showed elevated expression of Arginase 1, CD169, and TREM2 (triggering receptor expressed on myeloid cells 2)(Figure

290 4D), which are enriched on macrophages with known neuromodulatory functions (Colonna, 2003; Paloneva 291 et al., 2002; Ural et al., 2020). Thus, C1q-expressing intestinal macrophages are located near enteric neurons 292 and exhibit phenotypes characteristic of nerve-adjacent macrophages in other tissues. 
bioRxiv preprint doi: https://doi.org/10.1101/2022.01.27.478097; this version posted January 28, 2022. The copyright holder for this preprint (which was not certified by peer review) is the author/funder, who has granted bioRxiv a license to display the preprint in perpetuity. It is made available under aCC-BY 4.0 International license.

A

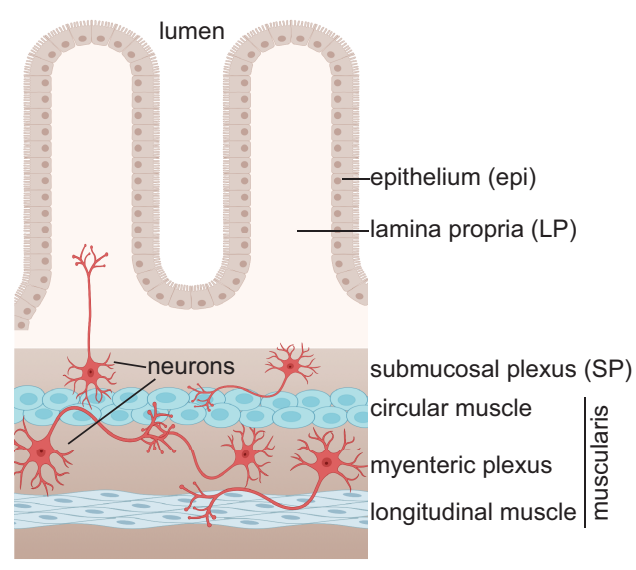

C

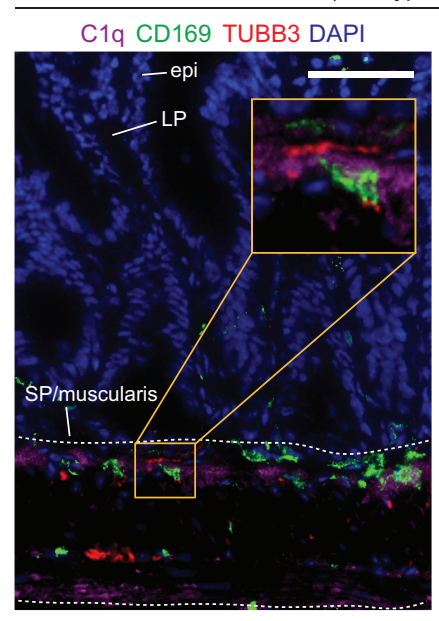

B

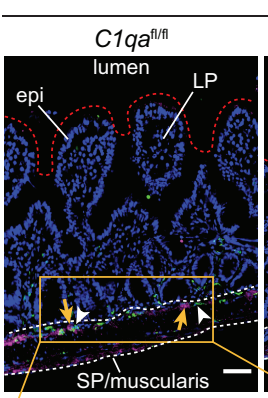

C1qa ${ }^{\mathrm{fl} / \mathrm{fl}}$

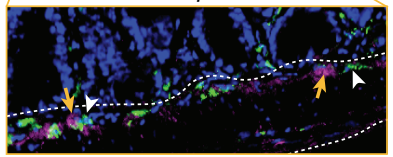

C1q CD169 DAPI

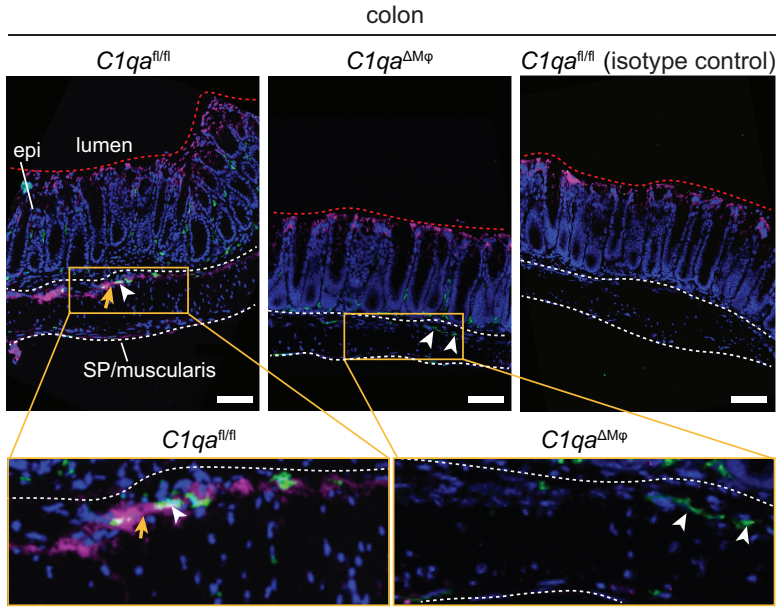

C1q CD169 DAPI

small intestine

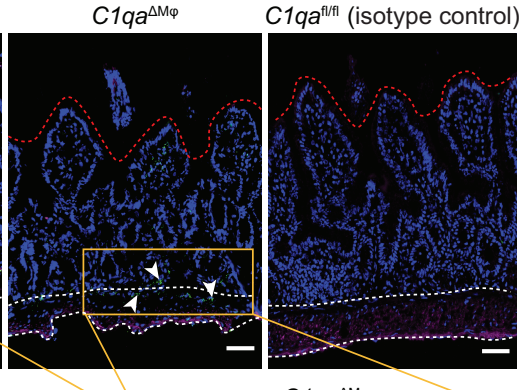

$C 1 q a^{\Delta M \varphi}$

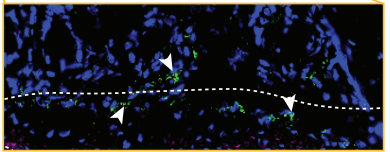

colon

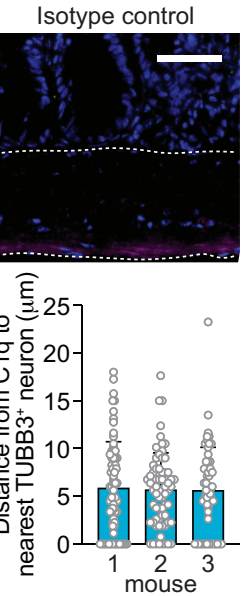

E

D

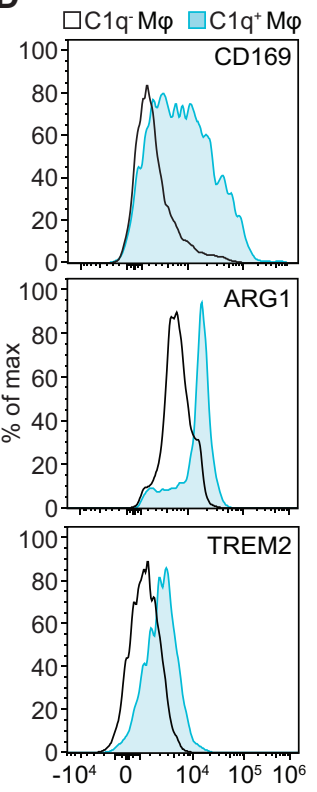

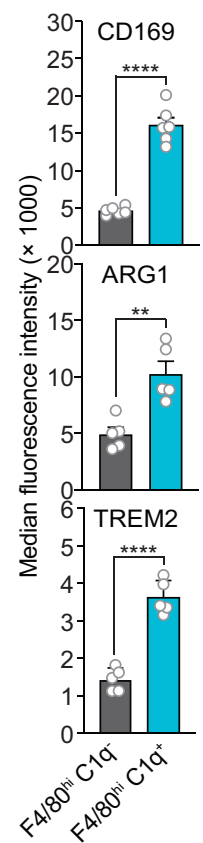

GO analysis of $C 1 q a^{\Delta \mathrm{M} \varphi}$ vs. C1qa $a^{\mathrm{f} / \mathrm{fl}}$

Synapse organization Synapse assembly Cell adhesion

Trans-synaptic signaling Neuron projection development Dendrite development Axon development Synaptic vesicle transport Dendrite morphogenesis Neuron projection guidance Neurotransmitter secretion Cell-cell adhesion Glutamatergic synaptic transmission Synapse structure/activity Regulation of membrane potential $T$ helper cell 1 differentiation Neurotransmitter transportation Regulation of secretory pathway(s) Regulation of exocytosis

Postsynapse organization Nervous system development Cation channel activity

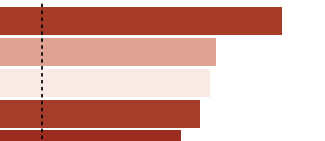

$\mathbf{F}$

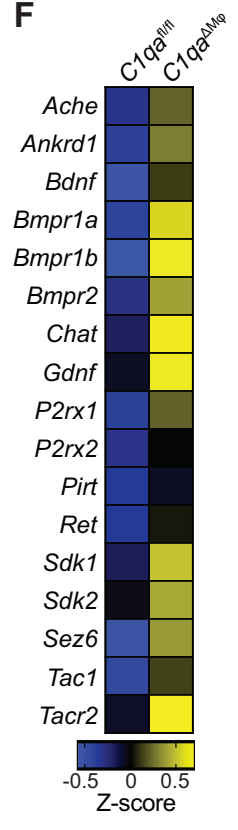


Figure 4. C1q-expressing macrophages are closely associated with neurons in the mouse intestine. (A) Graphic depicting the muscularis of the mouse small intestine. The lumen, epithelium (epi), lamina propria (LP), submucosal plexus (SP), and distinct anatomical regions of the muscularis are indicated. Created at Biorender.com (B) Immunofluorescence detection of C1q (violet) and macrophages marked with CD169 (green) in the small intestine and colon of $C l q a^{\mathrm{fl} / \mathrm{fl}}$ and $C l q a^{\Delta \mathrm{M} \varphi}$ littermates. Nuclei were detected with 4',6-diamidino-2-phenylindole (DAPI; blue). Detection with isotype control antibodies on Clqa ${ }^{\mathrm{fl} / \mathrm{fl}}$ small intestines is shown at right. Anti-rat IgG AlexaFluor 488 and streptavidin-Cy5 were used as secondary stains for CD169 and C1q respectively. The intestinal surface is denoted with a red dotted line and the gut lumen, epithelium, and lamina propria are indicated. The approximate region encompassing the submucosal plexus and the muscularis is denoted with two white dotted lines. Examples of $\mathrm{Clq}^{+}$ areas are indicated with yellow arrows and examples of $\mathrm{CD} 169^{+}$macrophages are indicated with white arrowheads. Note that the violet staining near the bottom of the muscularis is non-specific, as indicated by its presence in the isotype control image. Images are representative of three independent experiments. Scale bars $=50 \mu \mathrm{m}$.

(C) Immunofluorescence detection of C1q (violet), macrophages marked with CD169 (green) and neurons marked with TUBB3 (red) in the small intestines of wild-type C57BL/6 mice. Nuclei are detected with DAPI (blue). The epithelium, lamina propria are indicated. The approximate region encompassing the submucosal plexus and the muscularis is denoted with two white dotted lines. The expanded image area delineated by a yellow square shows an example of the close association between $\mathrm{Clq}$ and $\mathrm{TUBB}^{+}$neurons. Images are representative of images captured from three mice. Anti-rat IgG AlexaFluor 488, anti-rabbit IgG AlexaFluor 594, and streptavidin-Cy5 were used as secondary stains for CD169, TUBB3, and C1q respectively, and an isotype control image is shown at upper right. Scale bars $=50 \mu \mathrm{m}$. Lower right panel: Distances between $\mathrm{Clq}^{+}$areas and the nearest $\mathrm{TUBB}^{+}$neurons were measured in images captured from three mice. Each data point represents one measurement and measurements were made on 10 to 15 microscopic fields for each mouse (71, 70, and 57 total measurements, respectively).

(D) Flow cytometry analysis of CD169, Arginase 1, and TREM2 on $\mathrm{Clq}^{-}$and $\mathrm{C}_{1 \mathrm{q}^{+}}$macrophages recovered from the small intestines of wild-type C57BL/6 mice. Median fluorescence intensities from multiple mice are quantified in the panels at right. Each data point represents one mouse $(\mathrm{n}=5-6$ mice), and results are representative of two independent experiments. Error bars represent SEM. ${ }^{* *} \mathrm{p}<0.01 ; * * * * \mathrm{p}<0.0001$ by two-tailed Student's t-test.

(E) Colonic longitudinal muscle myenteric plexus was acquired from $C 1 q a^{\Delta \mathrm{M \varphi}}$ and $C 1 q a^{\mathrm{fl} / \mathrm{fl}}$ littermates. RNA-seq was performed, and annotated gene ontology (GO) biological processes were assigned to genes that were differentially expressed in $C l q a^{\Delta \mathrm{M} \varphi}$ mice when compared to their Clq $a^{\mathrm{fl} / \mathrm{fl}}$ littermates. GO biological processes associated with neurons are in bold type. The dotted line indicates the cutoff for statistical significance. Five mice per group were analyzed as pooled biological replicates. Data are available from the Sequence Read Archive under BioProject ID PRJNA793870.

(F) Heat map of representative neuron-related genes differentially expressed in the colonic longitudinal muscle myenteric plexus of $C l q a^{\Delta \mathrm{M} \varphi}$ mice relative to $C l q a^{\mathrm{fl} / \mathrm{fl}}$ littermates. Five mice per group were analyzed as pooled biological replicates.

Figure supplement 1. Similar numbers of $\mathrm{CD} 169^{+}$macrophages are recovered from the small intestines of $C 1 q a^{\Delta \mathrm{M} \varphi}$ and $\mathrm{Cl}_{\mathrm{q}} \mathrm{a}^{\mathrm{f} / \mathrm{fl}}$ littermates.

Figure supplement 2. The colonic muscle myenteric plexus of $C l q a^{\Delta \mathrm{M} \varphi}$ mice has a transcriptional profile similar to that of mice with a gastrointestinal motility disorder.

\section{$C 1 q a^{\Delta \mathrm{M} \phi}$ mice have altered gastrointestinal motility}

Macrophages engage in crosstalk with the enteric nervous system and regulate functions, including

338 gastrointestinal motility, that depend on the enteric nervous system (Muller et al., 2014). This crosstalk

339 involves the exchange of specific proteins such as bone morphogenetic protein 2 (BMP2) (Muller et al.,

340 2014). Given that $\mathrm{Clq}^{+}$macrophages phenotypically resemble peripheral nerve-adjacent macrophages and 
reside near enteric neurons, we postulated that macrophage-derived C1q might also regulate enteric nervous system function.

As an initial test of this idea, we performed RNA-seq on the colonic longitudinal muscle-myenteric

344 plexus from $C 1 q a^{\Delta \mathrm{M} \phi}$ and $C 1 q a^{\mathrm{fl} / \mathrm{fl}}$ littermates and then conducted unbiased Gene Set Enrichment Analysis.

345 Of the 22 biological pathways that were enriched in $C 1 q a^{\Delta \mathrm{M} \phi}$ mice, 18 were related to neuronal development

346 or function, including synapse organization, dendrite development, and neurotransmitter secretion (Figure

$347 \boldsymbol{4 E}$ and $\boldsymbol{F}$ ). 30 genes were differentially expressed when comparing the muscle-myenteric plexus of $348 C l q a^{\Delta \mathrm{M} \phi}$ and $C l q a^{\mathrm{fl} / \mathrm{fl}}$ mice. These included genes with known roles in regulating neuronal activity 349 (Dusp26), synaptic transmission (Rasgrf2), and neuropeptide signaling (Tacr2) (Mao et al., 2017; 350 Schwechter et al., 2013; Yang et al., 2017). We also compared the list of genes differentially expressed in 351 the $C l q a^{\Delta \mathrm{M \phi}}$ mice to those differentially expressed in the TashT mouse line. This line contains an insertional 352 mutation that leads to a gut motility disorder comparable to Hirschsprung's disease, a human genetic 353 disorder resulting in incomplete development of the enteric nervous system (Bergeron et al., 2015). There 354 was a statistically significant overlap in the transcriptional changes in the colonic longitudinal musclemyenteric plexus of Clqa $a^{\Delta \mathrm{M \phi}}$ mice and TashT mice (Figure 4 - figure supplement 2). Together, these results suggested that macrophage $\mathrm{C} 1 \mathrm{q}$ impacts enteric nervous system gene expression and function. Efficient coordination of gastrointestinal motility is necessary for proper digestion, nutrient absorption, and excretion. Given that muscularis macrophages regulate enteric nervous system functions that govern gastrointestinal motility (Muller et al., 2014), we assessed whether macrophage C1q impacts

360 gut motility. We first tested this idea by measuring gut transit time using the nonabsorbable dye carmine 361 red. $C l q a^{\Delta \mathrm{M} \phi}$ and $C l q a^{\mathrm{fl} / \mathrm{fl}}$ littermates were gavaged with the dye and the time to first appearance of the dye

362 in the feces was recorded. Transit times were decreased in $C 1 q a^{\Delta \mathrm{M} \phi}$ mice relative to their $C 1 q a^{\mathrm{fl} / \mathrm{fl}}$ 363 littermates, indicating accelerated gut motility (Figure 5A). This was not due to a change in the lengths of 364 either the small intestine or the colon, which were unaltered in the $C 1 q a^{\Delta \mathrm{M} \phi}$ mice (Figure 5B). By contrast, 365 gut transit time was unaltered in $C 3^{-/}$mice, suggesting that macrophage $\mathrm{C} 1 \mathrm{q}$ impacts gut motility 
(Figure 5C). We then conducted ex vivo colonic peristaltic recordings and observed that the colons of

figure supplement 1). This suggested that the colons of $C l q a^{\Delta \mathrm{M} \phi}$ mice maintained increased peristaltic
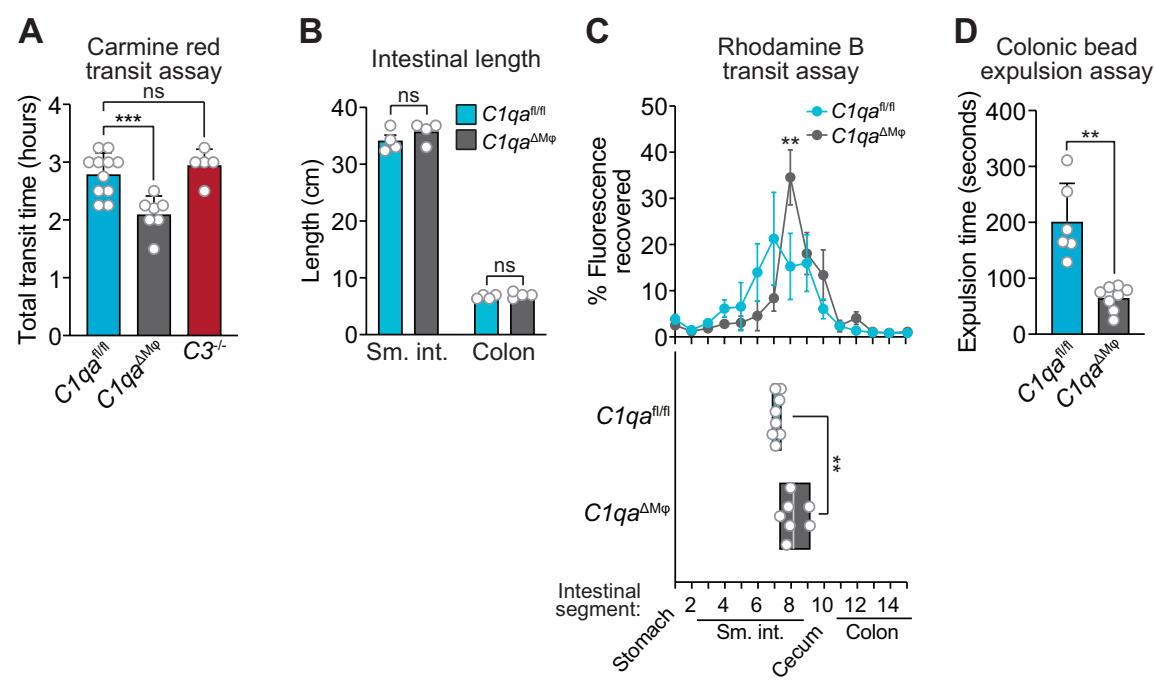

Figure 5. $C 1 q a^{\Delta \mathrm{M} \varphi}$ mice have altered gastrointestinal motility. with $100 \mu \mathrm{l}$ of carmine red (5\% (w/v in $1.5 \%$ methylcellulose). Fecal pellets were collected every 15 minutes and transit time was recorded when the dye was first observed in the feces. Each data point represents one mouse and the results are pooled from five independent experiments.

(B) Intestinal tract length is not altered in $C 1 q a^{\Delta \mathrm{M} \varphi}$ mice. Small intestines and colons from $C 1 q a^{\mathrm{fl} / \mathrm{fl}}$ and $C 1 q a^{\Delta \mathrm{M} \varphi}$ littermates were excised and measured. Each data point represents one mouse. 90 minutes after gavage with rhodamine B-dextran. The intestines were divided into 16 segments, the rhodamine B fluorescence was measured in each segment (top panel), and the geometric center of the fluorescence was determined for each mouse (bottom panel). Each data point represents one mouse and the results were pooled from four independent experiments. independent experiments. 
sm. int., small intestine. Error bars represent SEM. **p $<0.01 ; * * * \mathrm{p}<0.001 ;$ ns, not significant by two-tailed Student's t-test.

Figure supplements 1 and 2. Ex vivo video recordings of colonic peristalsis in $C 1 q a^{\mathrm{fl} / \mathrm{fl}}$ and $C 1 q a^{\Delta \mathrm{M} \varphi}$ littermates.

\section{DISCUSSION}

Here, we have identified a role for $\mathrm{C} 1 \mathrm{q}$ in regulating gastrointestinal motility. We discovered that nerve-adjacent macrophages are the primary source of $\mathrm{C} 1 \mathrm{q}$ in the mouse intestine and that macrophage $\mathrm{C} 1 \mathrm{q}$ regulates enteric neuronal gene expression and gastrointestinal transit time. Our findings reveal a previously unappreciated function for $\mathrm{C} 1 \mathrm{q}$ in the intestine and help to illuminate the molecular basis for macrophagemediated control of gut motility.

Our study identifies macrophages as the main source of $\mathrm{Clq}$ in the mouse small intestine and colon. Both transient antibody-mediated depletion of macrophages and in vivo deletion of the Clqa gene from macrophages led to a marked reduction in intestinal $C 1 q$ expression. The $C 1 q a^{\Delta \mathrm{M} \phi}$ mice also lacked $\mathrm{Clq}$ in the circulation, indicating that $\mathrm{LysM}^{+}$macrophages or macrophage-like cells are also the source of circulating $\mathrm{Clq}$ in the absence of infection. This enhances findings from prior studies indicating that monocytes, macrophages, and immature dendritic cells are the main sources of C1q in the bloodstream (ElShamy et al., 2018). Importantly, the $C 1 q a^{\Delta \mathrm{M} \phi}$ mice retained C1q expression in the brain, allowing us to analyze the effects of C1q deficiency without possible confounding effects on the central nervous system.

C1q has two known physiological functions that are distinct and vary according to tissue context. C1q was originally discovered as having a role in the classical complement pathway, which tags and destroys invading microbes (Noris and Remuzzi, 2013; Schifferli et al., 1986). Circulating C1q binds to invading microorganisms and recruits additional proteins that assemble into the membrane attack complex (MAC) (Kishore and Reid, 2000). C1q-mediated MAC formation has been primarily described in the bloodstream, where the necessary accessory proteins are present at high levels (Davis et al., 1979). However, $\mathrm{Clq}$ is also expressed in the absence of infection in tissues such as the brain, where it regulates neuronal development and function (Kouser et al., 2015; van Schaarenburg et al., 2016). 
Our findings suggest that $\mathrm{C} 1 \mathrm{q}$ does not play a central role in immune defense of the intestine. First, we found that intestinal C1q expression was not induced by gut commensals or pathogens and was not deposited into the gut lumen. Second, C1q deficiency did not markedly alter gut microbiota composition or the course of disease after DSS treatment. There were also no major changes in cytokine expression or numbers and frequencies of intestinal immune cells that would indicate dysregulated interactions with the microbiota. Third, C1q was not required for clearance of $C$. rodentium, a non-disseminating enteric pathogen whose clearance requires antigen-specific IgG and complement component 3 (C3) (Belzer et al., 2011). Although we cannot rule out a role for $\mathrm{C} 1 \mathrm{q}$ in immune defense against other intestinal pathogens, these findings support the idea that $\mathrm{C} 1 \mathrm{q}$ is not essential for intestinal immune defense in mice.

Instead, our results indicate that $\mathrm{Clq}$ influences enteric nervous system function and regulates intestinal motility. First, most C1q-expressing macrophages were localized to the intestinal submucosal plexus and were largely absent from the lamina propria. Second, C1q-expressing intestinal macrophages were located close to submucosal plexus neurons and expressed cell surface markers like those expressed by nerve-adjacent C1q-expressing macrophages in the lung (Ural et al., 2020). Third, macrophage-specific brain, where it regulates the development and function of neurons (Kouser et al., 2015; van Schaarenburg et al., 2016).

A function for macrophage $\mathrm{Clq}$ in intestinal motility adds to the growing understanding of how gut macrophages regulate intestinal peristalsis. Prior work has shown that $\mathrm{CSF}_{\mathrm{R}} \mathrm{R}^{+}$macrophages selectively

441 localize to the muscularis of the mouse intestine (Muller et al., 2014; Gabanyi et al., 2016). These 442 macrophages secrete BMP2, which activates enteric neurons that regulate colonic muscle contraction and 443 thus colonic motility (Muller et al., 2014). We found that depletion of CSF1 $\mathrm{R}^{+}$macrophages reduces 444 intestinal C1q expression, and that macrophage-specific deletion of Clqa alters enteric neuronal gene 
expression and gut motility. Thus, our findings suggest that $\mathrm{C} 1 \mathrm{q}$ is a key component of the macrophageenteric nervous system axis.

An important remaining question concerns the molecular mechanism by which $\mathrm{C} 1 \mathrm{q}$ regulates gut motility. One possibility is that $\mathrm{Clq}$ shapes microbiota composition which, in turn, impacts gut motility. This idea is suggested by studies in zebrafish showing that a deficiency in intestinal macrophages leads to altered gut microbiota composition relative to wild-type zebrafish (Earley et al., 2018). Other studies in zebrafish and mice have shown that severe defects in enteric nervous system development produce changes in gut microbiota composition that are linked to dysregulated gut motility (Rolig et al., 2017; Johnson et al., 2018). However, we did not observe marked changes in the composition of the gut microbiota in $C l q a^{\Delta \mathrm{M \phi}}$ mice, arguing against a central role for the microbiota in C1q-mediated regulation of gut motility. A second possibility is that the absence of $\mathrm{Clq}$ leads to immunological defects that alter gut transit time. This idea is suggested by studies showing that $\mathrm{T}$ cell cytokines can influence gastrointestinal motility (Akiho et al., 2011). However, this seems unlikely given the lack of pronounced immunological abnormalities in the intestines of $C 1 q a^{\Delta \mathrm{M} \phi}$ mice.

A third possibility is that $\mathrm{Clq}$ interacts directly with enteric neurons or glial cells. Like macrophage-produced BMP2 (Muller et al., 2014), C1q might bind to specific receptors on neurons to regulate their activity. In support of this idea, mouse enteric neurons express Adgrb1, which encodes BAI1 (Obata et al., 2020), a known C1q receptor on human neural stem cells (Benavente et al., 2020). Other studies have suggested that $\mathrm{C} 1 \mathrm{q}$ functions as a signaling effector on immune cells and neurons (Benoit \& Tenner, 2011; Ling et al., 2018). Macrophages have also been reported to restrain neurogenesis in the enteric nervous system through phagocytosis of apoptotic neurons (Kulkarni et al., 2017). Given that C1q can opsonize dying host cells (Botto et al., 1998; Korb and Ahearn, 1997), C1q could regulate enteric nervous system function by tagging apoptotic neurons for elimination. It is also possible that $\mathrm{C} 1 \mathrm{q}$ acts directly on enteric smooth muscle cells that regulate gut motility. Although we cannot rule out this 
possibility, our transcriptional profile of the colonic myenteric plexus of $C 1 q a^{\Delta \mathrm{M} \phi}$ mice suggests that most of the transcriptional changes were associated with neurons. regulates gut motility could suggest new strategies to prevent or treat these diseases. Additionally, most

\section{MATERIALS AND METHODS}

\begin{tabular}{|c|c|c|c|c|}
\hline $\begin{array}{c}\text { Reagent type (species) } \\
\text { or resource }\end{array}$ & Designation & $\begin{array}{l}\text { Source or } \\
\text { reference }\end{array}$ & Identifiers & $\begin{array}{c}\text { Additional } \\
\text { information }\end{array}$ \\
\hline $\begin{array}{l}\text { strain, strain background } \\
\text { (Mus musculus) }\end{array}$ & $\begin{array}{l}\text { C1qa } a^{\mathrm{fl} / f \mathrm{fl}} ; \mathrm{B6}(\mathrm{SJL})- \\
\text { C1qa }^{\mathrm{tm} \text { ic(EUCOMM)Wtsi } / T e n n J}\end{array}$ & $\begin{array}{l}\text { Jackson } \\
\text { Laboratory; } \\
\text { Fonseca et al., } \\
2017 \\
\end{array}$ & Stock \#031261 & \\
\hline $\begin{array}{l}\text { strain, strain background } \\
\text { (Mus musculus) }\end{array}$ & $\begin{array}{l}\text { LysM-Cre; B6.129P2- } \\
\text { Lyz2 }^{\text {tm1(cre)lfo/J }}\end{array}$ & $\begin{array}{l}\text { Jackson } \\
\text { Laboratory; } \\
\text { (Clausen et al., } \\
\text { 1999) } \\
\end{array}$ & Stock \#004781 & \\
\hline $\begin{array}{l}\text { strain, strain background } \\
\text { (Mus musculus) }\end{array}$ & $C 1 q a^{\Delta M \phi}$ & this paper & & $\begin{array}{l}\text { Generated by crossing } \\
\text { C1qa } \\
\text { Lys//fl mice with } \\
\text { Lys-Cre mice }\end{array}$ \\
\hline $\begin{array}{l}\text { strain, strain background } \\
\text { (Mus musculus) }\end{array}$ & $\mathrm{C}^{-/-} ; \mathrm{B} 6.129 \mathrm{~S} 4-\mathrm{C} 3^{\mathrm{tm} 1 \mathrm{Crr} / \mathrm{J}}$ & $\begin{array}{l}\text { Jackson } \\
\text { Laboratory; } \\
\text { Wessels et al., } \\
1995\end{array}$ & Stock \#029661 & \\
\hline $\begin{array}{l}\text { strain, strain background } \\
\text { (Mus musculus) }\end{array}$ & Germ-free C57BL/6J mice & $\begin{array}{l}\text { UT Southwestern } \\
\text { Gnotobiotics Core } \\
\text { Facility }\end{array}$ & & \\
\hline
\end{tabular}


bioRxiv preprint doi: https://doi.org/10.1101/2022.01.27.478097; this version posted January 28, 2022. The copyright holder for this preprint (which was not certified by peer review) is the author/funder, who has granted bioRxiv a license to display the preprint in perpetuity. It is made available under aCC-BY 4.0 International license.

\begin{tabular}{|c|c|c|c|c|}
\hline $\begin{array}{l}\text { Reagent type (species) } \\
\text { or resource }\end{array}$ & Designation & $\begin{array}{l}\text { Source or } \\
\text { reference }\end{array}$ & Identifiers & $\begin{array}{l}\text { Additional } \\
\text { information }\end{array}$ \\
\hline $\begin{array}{l}\text { strain, strain background } \\
\text { (Salmonella enterica) }\end{array}$ & $\begin{array}{l}\text { Salmonella enterica subsp. } \\
\text { enterica serovar Typhimurium } \\
\text { strain SL1344 }\end{array}$ & $\begin{array}{l}\text { Dr. Vanessa } \\
\text { Sperandio; } \\
\text { Eichelberg and } \\
\text { Galan, } 1999\end{array}$ & & \\
\hline $\begin{array}{l}\text { strain, strain background } \\
\text { (Citrobacter rodentium) }\end{array}$ & $\begin{array}{l}\text { Citrobacter rodentium strain } \\
\text { DBS100 }\end{array}$ & ATCC & Strain\# 51459 & \\
\hline antibody & $\begin{array}{l}\text { Anti-Actin HRP (rabbit } \\
\text { monoclonal) }\end{array}$ & Cell Signaling & Clone: 13E5 & Immunoblot (1:5000) \\
\hline antibody & $\begin{array}{l}\text { Anti-ARG1 (sheep } \\
\text { monoclonal) }\end{array}$ & R\&D Systems & Clone: P05089 & Flow $(1: 100)$ \\
\hline antibody & Anti-B220 (rat monoclonal) & ThermoFisher & Clone: RA3-6B2 & Flow (1:500) \\
\hline antibody & Anti-C1q (rat monoclonal) & $\begin{array}{l}\text { Cedarlane } \\
\text { Laboratories }\end{array}$ & Clone: $\mathrm{RmC7H8}$ & Flow $(1: 50)$ \\
\hline antibody & Anti-C1q (rabbit polyclonal) & ThermoFisher & Cat\# PA5-29586 & Immunoblot (1:500) \\
\hline antibody & $\begin{array}{l}\text { Anti-C1q-biotin (mouse } \\
\text { monoclonal) }\end{array}$ & Abcam & Clone: JL1 & $\begin{array}{l}\text { ELISA (1:1000); } \\
\text { Immunofluorescence } \\
(1: 100)\end{array}$ \\
\hline antibody & Anti-CD3 (rat monoclonal) & ThermoFisher & Clone: 17A2 & Flow $(1: 200)$ \\
\hline antibody & Anti-CD4 (rat monoclonal) & BioLegend & Clone: GK1.5 & Flow $(1: 500)$ \\
\hline antibody & Anti-CD11b (rat monoclonal) & ThermoFisher & Clone: M1/70 & Flow (1:200) \\
\hline antibody & $\begin{array}{l}\text { Anti-CD11c (Armenian } \\
\text { hamster monoclonal) }\end{array}$ & ThermoFisher & Clone: N418 & Flow (1:500) \\
\hline antibody & Anti-CD16/32 (rat monoclonal) & BioLegend & Clone: 93 & $\begin{array}{l}\text { Fc receptor block } \\
(1: 1000)\end{array}$ \\
\hline antibody & Anti-CD19 (rat monoclonal) & BioLegend & Clone: 1D3 & Flow $(1: 500)$ \\
\hline antibody & Anti-CD45 (rat monoclonal) & BioLegend & Clone: $30-\mathrm{F} 11$ & Flow $(1: 500)$ \\
\hline antibody & Anti-CD90.2 (rat monoclonal) & BioLegend & Clone: $30-\mathrm{H} 12$ & Flow $(1: 500)$ \\
\hline antibody & Anti-CD169 (rat monoclonal) & BioLegend & Clone: 3D6.112 & Flow $(1: 200)$ \\
\hline antibody & Anti-CD169 (rat monoclonal) & Abcam & Clone: 3D6.112 & $\begin{array}{l}\text { Immunofluorescence } \\
(1: 200)\end{array}$ \\
\hline antibody & Anti-CSF1R (rat monoclonal) & Bio X Cell & Cat\# AFS98 & $\begin{array}{l}\text { Macrophage depletion } \\
\text { (dosage) }\end{array}$ \\
\hline antibody & Anti-F4/80 & BioLegend & Clone: BM8 & Flow $(1: 100)$ \\
\hline antibody & Anti-FoxP3 (rat monoclonal) & ThermoFisher & Clone: FJK-16s & Flow $(1: 50)$ \\
\hline antibody & $\begin{array}{l}\text { Anti-GATA3 (mouse } \\
\text { monoclonal) }\end{array}$ & BD Biosciences & Clone: L50-823 & Flow $(1: 50)$ \\
\hline antibody & Anti-lgA (rat monoclonal) & ThermoFisher & Clone: $11-44-2$ & Flow $(1: 50)$ \\
\hline antibody & Anti-LY6C & BioLegend & Clone: RB6-8C5 & Flow $(1: 500)$ \\
\hline antibody & Anti-MHCII & Thermo & Clone: M5/114.15.2 & Flow (1:500) \\
\hline antibody & Anti-REG3G antiserum (rabbit) & $\begin{array}{l}\text { Cash et al., 2006; } \\
\text { antiserum } \\
\text { generated by } \\
\text { Pacific } \\
\text { Biosciences }\end{array}$ & & Immunoblot (dilution) \\
\hline antibody & Anti-ROR $\gamma \mathrm{t}$ & ThermoFisher & Clone: AFKJS-9 & Flow (1:50) \\
\hline antibody & Anti-T-BET & BioLegend & Clone: 4B10 & Flow (1:50) \\
\hline antibody & Anti-TREM2 & R\&D Systems & Clone: 237920 & Flow $(1: 200)$ \\
\hline antibody & Anti-TUBB3 & Abcam & Cat\# ab18207 & $\begin{array}{l}\text { Immunofluorescence } \\
(1: 200)\end{array}$ \\
\hline antibody & $\begin{array}{l}\text { Goat anti-rabbit IgG HRP } \\
\text { conjugate }\end{array}$ & Abcam & Cat\# ab6721 & Immunoblot $(1: 5000)$ \\
\hline antibody & $\begin{array}{l}\text { secondary antibodies - } \\
\text { AlexaFluor } 488 / 594 / 647\end{array}$ & Invitrogen & & $\begin{array}{l}\text { Immunofluorescence } \\
(1: 400)\end{array}$ \\
\hline antibody & mouse IgG1 & Abcam & Cat\# ab18443 & ELISA $(10 \mu \mathrm{g} / \mathrm{ml})$ \\
\hline antibody & Rat lgG2a & ThermoFisher & Clone: $2 \mathrm{~A} 3$ & $\begin{array}{l}\text { Isotype control for anti- } \\
\text { CSF1R macrophage } \\
\text { depletion }\end{array}$ \\
\hline antibody & Rat lgG1 PE isotype control & $\begin{array}{l}\text { Cedarlane } \\
\text { Laboratories }\end{array}$ & Cat\# CLCR104 & Flow $(1: 50)$ \\
\hline sequence-based reagent & mouse C1qa TaqMan assay & ThermoFisher & $\begin{array}{l}\text { Assay ID: } \\
\text { Mm00432142 m1 }\end{array}$ & \\
\hline
\end{tabular}


bioRxiv preprint doi: https://doi.org/10.1101/2022.01.27.478097; this version posted January 28, 2022. The copyright holder for this preprint (which was not certified by peer review) is the author/funder, who has granted bioRxiv a license to display the preprint in perpetuity. It is made available under aCC-BY 4.0 International license.

\begin{tabular}{|c|c|c|c|c|}
\hline $\begin{array}{l}\text { Reagent type (species) } \\
\text { or resource }\end{array}$ & Designation & $\begin{array}{l}\text { Source or } \\
\text { reference }\end{array}$ & Identifiers & $\begin{array}{l}\text { Additional } \\
\text { information }\end{array}$ \\
\hline sequence-based reagent & mouse $C 1 q b$ TaqMan assay & ThermoFisher & $\begin{array}{l}\text { Assay ID: } \\
\text { Mm01179619 m1 }\end{array}$ & \\
\hline sequence-based reagent & mouse C1qc TaqMan assay & ThermoFisher & $\begin{array}{l}\text { Assay ID: } \\
\text { Mm00776126 m1 }\end{array}$ & \\
\hline sequence-based reagent & mouse $\operatorname{Reg} 3 g$ TaqMan assay & ThermoFisher & $\begin{array}{l}\text { Assay ID: } \\
\text { Mm00441127_m1 }\end{array}$ & \\
\hline sequence-based reagent & mouse Ifng TaqMan assay & ThermoFisher & $\begin{array}{l}\text { Assay ID: } \\
\text { Mm01168134_m1 }\end{array}$ & \\
\hline sequence-based reagent & mouse //4 TaqMan assay & ThermoFisher & $\begin{array}{l}\text { Assay ID: } \\
\text { Mm00445259_m1 }\end{array}$ & \\
\hline sequence-based reagent & mouse IL5 TaqMan assay & ThermoFisher & $\begin{array}{l}\text { Assay ID: } \\
\text { Mm00439646_m1 }\end{array}$ & \\
\hline sequence-based reagent & mouse $/ / 10$ TaqMan assay & ThermoFisher & $\begin{array}{l}\text { Assay ID: } \\
\text { Mm01288386 m1 }\end{array}$ & \\
\hline sequence-based reagent & mouse //13 TaqMan assay & ThermoFisher & $\begin{array}{l}\text { Assay ID: } \\
\text { Mm00434204_m1 }\end{array}$ & \\
\hline sequence-based reagent & mouse I/17a TaqMan assay & ThermoFisher & $\begin{array}{l}\text { Assay ID: } \\
\text { Mm00439618 m1 }\end{array}$ & \\
\hline sequence-based reagent & mouse I/17f TaqMan assay & ThermoFisher & $\begin{array}{l}\text { Assay ID: } \\
\text { Mm00521423 m1 }\end{array}$ & \\
\hline sequence-based reagent & $\begin{array}{l}\text { mouse } 18 S \text { gene TaqMan } \\
\text { assay }\end{array}$ & ThermoFisher & $\begin{array}{l}\text { Assay ID: } \\
\text { Mm03928990_g1 }\end{array}$ & \\
\hline sequence-based reagent & $\begin{array}{l}\text { bacterial } 16 S \mathrm{~V} 3 \text { - rRNA gene } \\
\text { forward primer }\end{array}$ & $\begin{array}{l}\text { ThermoFisher; } \\
\text { (Klindworth et al., } \\
\text { 2013) }\end{array}$ & $\begin{array}{l}\text { 16S rRNA gene } \\
\text { sequencing }\end{array}$ & $\begin{array}{l}\text { 5'- } \\
\text { TCGTCGGCAGCGTC } \\
\text { AGATGTGTA } \\
\text { TAAGAGACAGCCTAC } \\
\text { GGGNGGCWGCAG-3' }\end{array}$ \\
\hline sequence-based reagent & $\begin{array}{l}\text { bacterial } 16 S \text { v } 4 \text { - rRNA gene } \\
\text { reverse primer }\end{array}$ & $\begin{array}{l}\text { ThermoFisher; } \\
\text { Klindworth et al., } \\
2013\end{array}$ & $\begin{array}{l}\text { 16S rRNA gene } \\
\text { sequencing }\end{array}$ & $\begin{array}{l}\text { 5'- } \\
\text { GTCTCGTGGGCTCG } \\
\text { GAGATGTGTA } \\
\text { TAAGAGACAGGACTA } \\
\text { CHVGGGTATCTAATC } \\
\text { C-3' }\end{array}$ \\
\hline $\begin{array}{l}\text { peptide, recombinant } \\
\text { protein }\end{array}$ & recombinant mouse $\mathrm{C} 1 \mathrm{q}$ & Complementech & Cat\# M099 & \\
\hline commercial assay or kit & $\begin{array}{l}\text { FOXP3/Transcription Factor } \\
\text { Fixation/Permeabilization } \\
\text { Buffer Set }\end{array}$ & ThermoFisher & Cat\# 00-5523-00 & \\
\hline commercial assay or kit & $\begin{array}{l}\text { MMLV Reverse Transcriptase } \\
\text { Kit }\end{array}$ & ThermoFisher & Cat\# 28025-021 & \\
\hline commercial assay or kit & $\begin{array}{l}\text { PE300 (Paired end } 300 \text { bp) v3 } \\
\text { kit }\end{array}$ & Illumina & Cat\# MS-102-3001 & \\
\hline commercial assay or kit & RNeasy Universal Mini Kit & Qiagen & Cat\# 73404 & \\
\hline commercial assay or kit & TaqMan Master Mix & ThermoFisher & Cat\# 4369542 & \\
\hline commercial assay or kit & $\begin{array}{l}\text { TruSeq RNA sample } \\
\text { preparation kit }\end{array}$ & Illumina & Cat\# RS-122-2001 & \\
\hline chemical compound, drug & Agencourt AmpureXP beads & $\begin{array}{l}\text { Beckman Coulter } \\
\text { Genomics }\end{array}$ & Cat\# A63880 & \\
\hline chemical compound, drug & Carmine Red & Sigma & Cat\# C1022-25G & \\
\hline chemical compound, drug & Collagenase IV & Sigma & Cat\# C5138-1G & \\
\hline chemical compound, drug & $\begin{array}{l}\text { Borosilicate glass beads } \\
(2 \mathrm{~mm})\end{array}$ & Millipore Sigma & Cat\# Z273627-1EA & \\
\hline chemical compound, drug & Dextran sulfate sodium & Thomas Scientific & Cat\# 216011090 & \\
\hline chemical compound, drug & DNase I & Sigma & Cat\# DN25 & \\
\hline chemical compound, drug & Dispase II & Sigma & Cat\# D4693-1G & \\
\hline chemical compound, drug & FITC-dextran & Sigma & Cat\# FD4-1g & \\
\hline chemical compound, drug & Ghost 710 & $\begin{array}{l}\text { Tonbo } \\
\text { Biosciences }\end{array}$ & Cat\# 13-0871-T100 & $\begin{array}{l}\text { Flow cytometry viability } \\
\text { dye }\end{array}$ \\
\hline chemical compound, drug & Methylcellulose & Sigma & Cat\# M0262-100G & \\
\hline chemical compound, drug & Nalidixic acid, sodium salt & $\begin{array}{l}\text { Research } \\
\text { Products } \\
\text { International }\end{array}$ & Cat\# N23100-25.0 & \\
\hline chemical compound, drug & $\begin{array}{l}\text { Optimal Cutting Temperature } \\
\text { Compound (OCT) }\end{array}$ & ThermoFisher & Cat\# 23-730-571 & \\
\hline chemical compound, drug & Percoll Plus & GE Healthcare & $\begin{array}{l}\text { Cat\# GE17-0891- } \\
09\end{array}$ & \\
\hline
\end{tabular}


bioRxiv preprint doi: https://doi.org/10.1101/2022.01.27.478097; this version posted January 28, 2022. The copyright holder for this preprint (which was not certified by peer review) is the author/funder, who has granted bioRxiv a license to display the preprint in perpetuity. It is made available under aCC-BY 4.0 International license.

\begin{tabular}{|c|c|c|c|c|}
\hline $\begin{array}{l}\text { Reagent type (species) } \\
\text { or resource }\end{array}$ & Designation & $\begin{array}{l}\text { Source or } \\
\text { reference }\end{array}$ & Identifiers & $\begin{array}{l}\text { Additional } \\
\text { information }\end{array}$ \\
\hline chemical compound, drug & Protease inhibitors & Millipore Sigma & Cat\# 11836153001 & \\
\hline chemical compound, drug & Rhodamine B-dextran & ThermoFisher & Cat\# D1841 & \\
\hline chemical compound, drug & Streptavidin-Cy5 & ThermoFisher & Cat\# 434316 & \\
\hline chemical compound, drug & Streptavidin-HRP conjugate & Abcam & Cat\# ab7403 & ELISA \\
\hline chemical compound, drug & $\begin{array}{l}\text { VECTASHIELD Antifade } \\
\text { Mounting Medium with DAPI }\end{array}$ & Vector Labs & Cat\# H-1200-10 & \\
\hline software, algorithm & clusterProfiler & & & \\
\hline software, algorithm & CLC Genomics Workbench & & & \\
\hline software, algorithm & $\begin{array}{l}\text { CLC Bio microbial genomics } \\
\text { module }\end{array}$ & & & $\begin{array}{l}\text { https:// } \\
\text { digitalinsights.qiagen.c } \\
\text { om/plugins/clc- } \\
\text { microbial-genomics- } \\
\text { module/ }\end{array}$ \\
\hline software, algorithm & FlowJo & & & \\
\hline software, algorithm & GraphPad PRISM & $\begin{array}{l}\text { GraphPad } \\
\text { Software }\end{array}$ & $\begin{array}{l}\text { Version 7.0; } \\
\text { RRID:SCR_002798 }\end{array}$ & \\
\hline software, algorithm & Igor Pro 9 & WaveMetrics & & \\
\hline software, algorithm & Illumina Nextera Protocol & Illumina & $\begin{array}{l}\text { Part \# } 15044223 \\
\text { Rev. B }\end{array}$ & \\
\hline software, algorithm & ImageJ & $\begin{array}{l}\text { National Institutes } \\
\text { of Health }\end{array}$ & & https://imagej.nih.gov/ij/ \\
\hline software, algorithm & NovoExpress & $\begin{array}{l}\text { Agilent } \\
\text { Technologies }\end{array}$ & & \\
\hline software, algorithm & PVCAM software & $\begin{array}{l}\text { Teledyne } \\
\text { Photometrics }\end{array}$ & & \\
\hline Other & Agilent 2100 Bioanalyzer & $\begin{array}{l}\text { Agilent } \\
\text { Technologies }\end{array}$ & G2939A & \\
\hline Other & Amicon Ultra centrifugal filters & Millipore & Cat \#UFC900324 & \\
\hline Other & $\begin{array}{l}\text { BioRad ChemiDoc Touch } \\
\text { System }\end{array}$ & BioRad & Cat\# 1708370 & \\
\hline Other & CMOS camera & $\begin{array}{l}\text { Teledyne } \\
\text { Photometrics }\end{array}$ & MOMENT & \\
\hline Other & Leica CM1950 (Cryostat) & Leica & & \\
\hline Other & FACSAria & BD Biosciences & & \\
\hline Other & Illumina MiSeq & Illumina & RRID:SCR_016379 & \\
\hline Other & Illumina NextSeq 500 & Illumina & & \\
\hline Other & $\begin{array}{l}\text { Keyence Fluorescence } \\
\text { Microscope }\end{array}$ & Keyence & BZ-X800 & \\
\hline Other & NovoCyte 3005 & $\begin{array}{l}\text { Agilent } \\
\text { Technologies }\end{array}$ & & \\
\hline Other & Organ bath chamber & $\begin{array}{l}\text { Tokai Hit Co. } \\
\text { (Japan) }\end{array}$ & & \\
\hline Other & Peristaltic pump & Gilson & MINIPULS3 & \\
\hline Other & $\begin{array}{l}\text { QuantStudio } 7 \text { Flex Real-Time } \\
\text { PCR System }\end{array}$ & $\begin{array}{l}\text { Applied } \\
\text { Biosystems }\end{array}$ & Cat \#4485701 & \\
\hline Other & SpectraMax M5 plate reader & Molecular Devices & & \\
\hline Other & $\begin{array}{l}\text { Zeiss Axio Imager M1 } \\
\text { Microscope }\end{array}$ & Zeiss & & \\
\hline
\end{tabular}

Mice

490 Wild-type C57BL/6J (Jackson Laboratory) and $C 3^{--}$mice (Jackson Laboratory; Wessels et al., 1995) were

491 bred and maintained in the SPF barrier facility at the University of Texas Southwestern Medical Center.

$492 C l q a^{\Delta \mathrm{M \phi}}$ mice were generated by crossing $C 1 q a^{\mathrm{fl} / \mathrm{fl}}$ mice (Jackson Laboratory; Fonseca et al., 2017) with a

493 mouse expressing Cre recombinase controlled by the macrophage-specific mouse Lyz2 promoter (LysM- 
Cre mice; Jackson Laboratory; Clausen et al., 1999). Mice 8 to 12 weeks of age were used for all experiments and cohoused littermates were used as controls. Both male and female mice were analyzed. Germ-free C57BL/6J mice were bred and maintained in isolators at the University of Texas Southwestern Medical Center. All procedures were performed in accordance with protocols approved by the Institutional Animal Care and Use Committees (IACUC) of the UT Southwestern Medical Center.

\section{Quantitative polymerase chain reaction (qPCR)}

501 Tissue RNA was isolated using the RNeasy Universal Mini kit (Qiagen, Hilden, Germany). Cellular RNA 502 was isolated using the RNAqueous Micro kit (ThermoFisher). cDNA was generated from the purified RNA 503 using the M-MLV Reverse Transcriptase kit (ThermoFisher). qPCR analysis was performed using TaqMan 504 primer/probe sets and master mix (ThermoFisher) on a Quant-Studio 7 Flex Real-Time PCR System 505 (Applied Biosystems). Transcript abundances were normalized to $18 S$ rRNA abundance. TaqMan probe assay IDs are provided in the Key Resources table.

\section{Isolation and analysis of intestinal immune cells}

509 Lamina propria (LP) cells were isolated from the intestine using a published protocol (Yu et al., 2013; Yu

510 et al., 2014). Briefly, intestines were dissected from mice and Peyer's patches were removed. Intestines

511 were cut into small pieces and thoroughly washed with ice-cold phosphate-buffered saline (PBS) containing

$5125 \%$ fetal bovine serum (PBS-FBS). Epithelial cells were removed by incubating intestinal tissues in Hank's

513 buffered salt solution (HBSS) supplemented with 2 mM EDTA, followed by extensive washing with PBS-

514 FBS. Residual tissues were digested twice with Collagenase IV (Sigma), DNase I (Sigma) and Dispase (BD

515 Biosciences) for 45 minutes at $37^{\circ} \mathrm{C}$ with agitation. Cells were filtered through $70 \mu \mathrm{m}$ cell strainers

516 (ThermoFisher) and applied onto a 40\%:80\% Percoll gradient (GE Healthcare). Subepithelial cell

517 populations were recovered at the interface of the $40 \%$ and $80 \%$ fractions. For small intestinal cell

518 suspensions, the epithelial fraction was kept and combined with enzymatically liberated subepithelial cells.

519 Cells were washed with $2 \mathrm{mM}$ EDTA/3\% FBS in PBS and Fc receptors were blocked with anti-CD16/32 
520 (93). Cells were then stained with the viability dye Ghost 710 (Tonbo Biosciences) followed by antibodies

521 against cell surface markers including anti-CD45 (30-F11), anti-CD11b (M1/70), anti-MHCII

522 (M5/114.15.2), anti-F4/80 (BM8), anti-CD3 (17A2), anti-CD4 (GK1.5), anti-CD19 (1D3), anti-B220

523 (RA3-6B2), anti-CD11c (N418), anti-CD169 (3D6.112), anti-TREM2 (237920) and anti-LY6C (RB6-

524 8C5). Cells were fixed and permeabilized with the eBioscience FOXP3/Transcription Factor

525 Fixation/Permeabilization buffer set (ThermoFisher) and then subjected to intracellular staining with anti-

526 C1Q (RmC7H8), anti-FOXP3 (FJK-16s), anti-GATA3 (L50), anti-T-BET (4B10), anti-ROR $($ AFKJS-9),

527 and anti-ARG1 (P05089). Cells were sorted using a FACSAria (BD Biosciences) or analyzed using a

528 NovoCyte 3005 (Agilent Technologies). Data were processed with FlowJo software (BD Biosciences) or

529 NovoExpress (Agilent Technologies).

\section{Macrophage depletion}

532 Anti-mouse CSF1R (ThermoFisher; AFS98) and rat IgG2a isotype control (ThermoFisher; 2A3) antibodies

533 were administered intraperitoneally at a concentration of $100 \mathrm{mg} / \mathrm{kg}$. Mice were sacrificed 72 hours post-

534 injection and terminal ileum and colon were collected for qPCR analysis.

\section{Protein extraction from intestinal cells and feces}

537 To isolate proteins from intestinal cell suspensions, cell pellets were resuspended in $100 \mu$ of RIPA Lysis

538 Buffer (ThermoFisher) supplemented with protease inhibitors (Millipore Sigma) and vortexed vigorously

539 every 5 minutes for 20 minutes. Lysates were cleared of cellular debris by centrifugation at $13000 g$ for 5

540 minutes. To isolate proteins from the intestinal lumen, the entire gastrointestinal tract (from duodenum to

541 distal colon) was recovered from five wild-type C57BL/6J mice. The intestines were flushed with a total of

$542 \sim 50 \mathrm{ml}$ cold PBS containing protease inhibitors (Millipore Sigma, 11836153001). The flushes and fecal

543 pellets were homogenized by rotor and stator (TH Tissue Homogenizer; OMNI; TH01) and large particles

544 were centrifuged at $100 \mathrm{~g}$ for $10 \mathrm{~min}$ at room temperature. The supernatants were carefully decanted and 
centrifuged further at $3000 \mathrm{~g}$ for $20 \mathrm{~min}$ at room temperature. The clarified supernatants were precipitated with $40 \%$ ammonium sulfate overnight at $4{ }^{\circ} \mathrm{C}$. Precipitated protein was centrifuged at $3000 \mathrm{~g}$ for $30 \mathrm{~min}$ at $4^{\circ} \mathrm{C}$, then resuspended in cold $40 \%$ ammonium sulfate and centrifuged again. The pellets were resuspended in room temperature PBS and allowed to mix for $10 \mathrm{~min}$. Protein concentrations were determined by Bradford assay (BioRad).

\section{Immunoblot}

$55250 \mu \mathrm{g}$ of fecal protein or $25 \mu \mathrm{g}$ of cellular protein was loaded onto a 4-20\% gradient SDS-PAGE and transferred to a PVDF membrane. Membranes were blocked in 5\% nonfat dry milk in Tris-buffered saline (TBS) with $0.1 \%$ Tween-20 and then incubated overnight with the following primary antibodies: anti-C1Q membranes with rabbit anti-REG3G antiserum (Cash et al., 2006). After washing, membranes were incubated with goat anti-rabbit IgG HRP and then visualized with a BioRad ChemiDoc Touch system.

\section{Enzyme-linked immunosorbent assay (ELISA)}

560 Mouse C1q ELISA was performed as previously described (Petry et al., 2001). Briefly, microtiter plates 561 were coated overnight with mouse IgG1 and were then blocked with 5\% BSA in PBS. Serum samples were 562 diluted 1:50 and plated for 1 hour at room temperature. After washing with $0.05 \%$ Tween-20 in PBS, bound 563 C1q was incubated with biotinylated anti-C1q antibody (JL1, Abcam). Biotinylated anti-C1q was detected 564 with a streptavidin-HRP conjugate (Abcam). Optical density was measured using a wavelength of $492 \mathrm{~nm}$. 565 Plates were then analyzed using a SpectraMax M5 microplate reader (Molecular Devices).

\section{Intestinal permeability assay}

568 Intestinal permeability assays were performed by treating mice with fluorescein isothiocyanate dextran 569 (FITC-dextran) by oral gavage. The non-steroidal anti-inflammatory drug (NSAID) indomethacin was administered to mice as a positive control. For the experimental group, mice were treated with $190 \mu 17 \%$ 

$190 \mu$ indomethacin $(1.5 \mathrm{mg} / \mathrm{ml}$ in $7 \%$ DMSO in PBS) by oral gavage. After 1 hour, all mice were treated with $190 \mathrm{ul} \mathrm{FITC-dextran}(80 \mathrm{mg} / \mathrm{ml}$ in PBS) by oral gavage. Mice were sacrificed after 4 hours and sera were collected. Serum samples were centrifuged for 20 minutes at $4{ }^{\circ} \mathrm{C}$ at $800 \mathrm{~g}$ and supernatants were collected. Serum FITC-dextran levels were measured by a fluorescence microplate assay against a standard curve using a Spectramax plate reader (Molecular Devices).

\section{Dextran sulfate sodium (DSS) treatment}

579 Age and sex-matched mice were provided with 3\% dextran sulfate sodium (weight/volume) in autoclaved drinking water for 7 days. Animal weight and health were monitored in accordance with institutional IACUC guidelines.

\section{Salmonella Typhimurium infection}

584 To prepare bacteria for infection, Salmonella enterica serovar Typhimurium (SL1344) was cultured in 585 Luria-Bertani (LB) broth containing $50 \mu \mathrm{g} / \mathrm{ml}$ streptomycin in a shaking incubator at $37^{\circ} \mathrm{C}$ (Eichelberg and 586 Galan, 1999). The overnight culture was diluted the next day and grown to mid-log phase $\left(\mathrm{OD}_{600}=0.3-\right.$ 587 0.5). $C l q a^{\mathrm{fl} / \mathrm{fl}}$ and $C l q a^{\Delta \mathrm{M} \phi}$ littermates were inoculated intragastrically with $10^{9} \mathrm{CFU}$. All mice were 588 sacrificed 24 hours later and small intestinal tissues were harvested for analysis.

\section{Citrobacter rodentium infection}

591 To prepare bacteria for infection, an overnight culture of $C$. rodentium (DBS100, ATCC) in LB broth 592 containing nalidixic acid $(100 \mu \mathrm{g} / \mathrm{ml})$ in a shaking incubator at $37^{\circ} \mathrm{C}$. The overnight culture was diluted the 593 next day and grown to mid-log phase $\left(\mathrm{OD}_{600}=0.4-0.6\right)$. Bacteria were pelleted, washed, and resuspended

594 in PBS. Sex-matched littermates were inoculated intragastrically with $5 \times 10^{8} \mathrm{CFU}$. Fecal pellets were 
595

596

597

598

599

600

601

602

603

604

605

606

607

608

609

610

collected at a fixed time every 48 hours, homogenized in sterile PBS, diluted, and plated on LB agar with nalidixic acid $(100 \mu \mathrm{g} / \mathrm{ml})$.

\section{Immunofluorescence analysis of mouse intestines}

Mouse small intestines and colons were flushed with PBS and embedded with Optimal Cutting Temperature compound (OCT) (ThermoFisher). Sections were fixed in ice cold acetone, blocked with 1\% BSA, 10\% FBS, $1 \%$ Triton X-100 in PBS, and then incubated overnight at $4^{\circ} \mathrm{C}$ with the following antibodies: mouse anti-C1q biotin (JL-1), rat anti-CD169 (3D6.112), and rabbit anti-TUBB3 (ab18207, Abcam). Slides were then washed with PBS containing 0.2\% Tween-20 (PBS-T) and incubated with donkey anti-rabbit AlexaFluor 488, donkey anti-rat AlexaFluor 594, and Streptavidin-Cy5 (ThermoFisher) for 1 hour at room temperature in the dark. Slides were then washed in PBS-T and mounted with DAPI-Fluoromount-G (Southern Biotech). Mounted slides were cured overnight at $4^{\circ} \mathrm{C}$ until imaging.

\section{RNA-seq analysis of colonic longitudinal muscle myenteric plexus}

The colonic longitudinal muscle-myenteric plexus was collected from five age and sex matched $C l q a^{\mathrm{fl} / \mathrm{fl}}$ and $C l q a^{\Delta \mathrm{M \phi}}$ mice by manual dissection using a $2 \mathrm{~mm}$ metal probe (Fisher Scientific). RNA was isolated using the RNeasy Mini kit according to the manufacturer's protocol (Qiagen). Quantity and quality of RNA samples was assessed on an Agilent 2100 Bioanalyzer (Agilent Technologies). RNA sequencing libraries were prepared using the TruSeq RNA sample preparation kit (Illumina) according to the manufacturer's protocol. Libraries were validated on an Agilent Bionalyzer 2100. Indexed libraries were sequenced on an Illumina NextSeq550 for single-end 75 bp length reads. CLC Genomics Workbench 7 was used for bioinformatics and statistical analysis of the sequencing data. The approach used by CLC Genomics Workbench is based on a method developed previously (Mortazavi et al., 2008). To identify differentially enriched biological pathways, all genes were ranked based on their $\log _{2}$ fold change and pathway enrichment was identified using the R packages "clusterProfiler" and "msigdbr". For analysis of 
differentially expressed genes, gene counts were analyzed using DESeq-2 and differentially expressed genes were defined as having an adjusted $p$ value $<0.05$. A Fisher's Exact Test was conducted to assess the overlap between differentially expressed genes in $C 1 q a^{\Delta \mathrm{M} \phi}$ mice and the TashT mouse (Bergeron et al., 623 2015).

\section{$16 S$ rRNA gene sequencing and analysis}

The hypervariable regions V3 and V4 of the bacterial $16 S$ rRNA gene were prepared using the Illumina were done using the CLC Microbial Genomics Module. Individual sample reads were annotated with the

637 Greengene database and taxonomic features were assessed.

\section{Gastrointestinal motility assays}

640 Motility assays were adapted from previous studies (Luo et al., 2018; Maurer, 2016; Muller et al., 2014).

641 To determine transit time through the entire gastrointestinal tract, mice were fasted overnight and water 642 was removed 1 hour prior to the start of the experiment. Mice were then singly housed for 1 hour and then 643 gavaged with $100 \mu \mathrm{l}$ of carmine red (5\% weight/volume; Sigma) in 1.5\% methylcellulose. Fecal pellets

644 were collected every 15 minutes and transit time was recorded when the dye was first observed in the feces. 

recovered) $\times 100$.

\section{Ex vivo peristaltic imaging}

661 Ex vivo video imaging and analysis of colonic peristalsis was carried out as described previously (Obata et 662 al., 2020). Colons were dissected, flushed with sterile PBS, and pinned into an organ bath chamber (Tokai 663 Hit, Japan) filled with high glucose Dulbecco's Modified Eagle Medium (DMEM). DMEM was oxygenated $664\left(95 \% \mathrm{O} 2\right.$ and 5\% $\left.\mathrm{CO}_{2}\right)$, run through the chamber using a peristaltic pump (MINIPULS 3, Gilson) and kept 665 at $37^{\circ} \mathrm{C}$. Colons were allowed to equilibrate to the organ chamber for 30 minutes before video recording.

666 Movies of colonic peristalsis were captured with a camera (MOMENT, Teledyne photometrics) using 667 PVCAM software (500ms time-lapse delay) over 15 minutes. 


\section{Statistical analysis}

671 Graphed data are presented as means \pm standard error of the mean (SEM). Statistics were determined with

672 GraphPad Prism software. Statistical analyses were performed using two-tailed Student's t test when

673 comparing two groups, one way ANOVA when comparing multiple groups, and Fisher's exact test to assess

674 overlap between groups of differentially expressed genes. The statistical tests used are indicated in the

675 figure legends. $* P \leq 0.05 ; * * P \leq 0.01 ; * * P \leq 0.001$; and ns, $P>0.05$.

\section{ADDITIONAL INFORMATION}

\section{Acknowledgements}

We thank Shai Bel for assistance with immunofluorescence imaging experiments, the UT Southwestern

Genomics Core for assistance with RNA sequencing experiments, and the UT Southwestern Flow

Competing interests: The authors declare no competing interests.

\section{Author contributions}

692 Mihir Pendse, Conceptualization, Investigation, Data curation, Formal analysis, Methodology, Supervision, 693 Writing - original draft, Writing - review and editing; Yun Li, Investigation; Cristine N. Salinas, 694 Investigation; Gabriella Quinn, Data curation, Formal analysis; Daniel C. Propheter, Investigation, Writing

695 - review and editing; Chaitanya Dende, Investigation, Writing - review and editing; Alexander A. Crofts, 
Data curation, Formal analysis; Eugene Koo, Methodology; Brian Hassell, Investigation; Kelly A. Ruhn,

Methodology, Writing - original draft, Writing - review and editing; Lora V. Hooper, Conceptualization,

Funding acquisition, Supervision, Writing - original draft, Writing - review and editing.

\section{Data availability}

$16 S$ rRNA gene sequencing data (Figure 3D) and RNA sequencing data (Figure $4 \boldsymbol{E}$ and F; Figure 4 -

figure supplement 2) are available from the Sequence Read Archive under BioProject ID PRJNA793870.

704 All mouse strains used are available commercially.

705

706

707

708

709

710

711

712

713

714

715

716

717

718

719

720

721

722

723

724

725

726

727

728

729

730

731

732

733

734

735

\section{REFERENCES}

Akiho, H., Ihara, E., Motomura, Y., Nakamura, K. (2011). Cytokine-induced alterations of gastrointestinal motility in gastrointestinal disorders. World $J$ Gastrointest Pathophysiol, 2, 72-81. https://doi.org/10.4291/wjgp.v2.i5.72

Bassotti, G., Antonelli, E., Villanacci, V., Salemme, M., Coppola, M., Annese, V. (2014). Gastrointestinal motility disorders in inflammatory bowel diseases. World $J$ Gastroenterol, 20, 37-44. https://doi.org/10.3748/wjg.v20.i1.37

Belzer, C., Liu, Q., Carroll, M. C., Bry, L. (2011). The role of specific IgG and complement in combating a primary mucosal infection of the gut epithelium. Eur J Microbiol Immunol (Bp), 1, 311-318. https://doi.org/10.1556/EuJMI.1.2011.4.7

Benavente, F., Piltti, K.M., Hooshmand, M.J., Nava, A.A., Lakatos, A., Feld, B.G., Creasman, D., Gershon, P.D., Anderson, A. (2020). Novel C1q receptor-mediated signaling controls neural stem cell behavior and neurorepair. eLife, 9, e55732. https://doi.org/10.7554/eLife.55732

Benoit, M. E., Tenner, A. J. (2011). Complement protein C1q-mediated neuroprotection is correlated with regulation of neuronal gene and microRNA expression. $J$ Neurosci, 31, 3459-3469. https://doi.org/10.1523/JNEUROSCI.3932-10.2011

Bergeron, K. F., Cardinal, T., Toure, A. M., Beland, M., Raiwet, D. L., Silversides, D. W., Pilon, N. (2015). Male-biased aganglionic megacolon in the TashT mouse line due to perturbation of silencer elements in a large gene desert of chromosome 10. PLoS Genet, 11, e1005093. https://doi.org/10.1371/journal.pgen.1005093 
Bogunovic, M., Ginhoux, F., Helft, J., Shang, L., Hashimoto, D., Greter, M., Liu, K., Jakubzick, C., Ingersoll, M. A., Leboeuf, M., Stanley, E. R., Nussenzweig, M., Lira, S. A., Randolph, G. J., Merad, M. (2009). Origin of the lamina propria dendritic cell network. Immunity, 31, 513-525. https://doi.org/10.1016/j.immuni.2009.08.010

Bossi, F., Tripodo, C., Rizzi, L., Bulla, R., Agostinis, C., Guarnotta, C., Munaut, C., Baldassarre, G., Papa, G., Zorzet, S., Ghebrehiwet, B., Ling, G. S., Botto, M., Tedesco, F. (2014). C1q as a unique player in angiogenesis with therapeutic implication in wound healing. Proc Natl Acad Sci U S A, 111, 4209-4214. https://doi.org/10.1073/pnas.1311968111

Botto, M., Dell'Agnola, C., Bygrave, A. E., Thompson, E. M., Cook, H. T., Petry, F., Loos, M., Pandolfi, P. P., Walport, M. J. (1998). Homozygous C1q deficiency causes glomerulonephritis associated with multiple apoptotic bodies. Nat Genet, 19, 56-59. https://doi.org/10.1038/ng0598-56

Cao, W., Bobryshev, Y. V., Lord, R. S., Oakley, R. E., Lee, S. H., Lu, J. (2003). Dendritic cells in the arterial wall express C1q: potential significance in atherogenesis. Cardiovasc Res, 60, 175-186. https://doi.org/10.1016/s0008-6363(03)00345-6

Casals, C., Garcia-Fojeda, B., Minutti, C. M. (2019). Soluble defense collagens: Sweeping up immune threats. Mol Immunol, 112, 291-304. https://doi.org/10.1016/j.molimm.2019.06.007

Cash, H. L., Whitham, C. V., Behrendt, C. L., Hooper, L. V. (2006). Symbiotic bacteria direct expression of an intestinal bactericidal lectin. Science, 313, 1126-1130. https://doi.org/10.1126/science.1127119

Chu, Y., Jin, X., Parada, I., Pesic, A., Stevens, B., Barres, B., Prince, D. A. (2010). Enhanced synaptic connectivity and epilepsy in C1q knockout mice. Proc Natl Acad Sci U S A, 107, 7975-7980. https://doi.org/10.1073/pnas.0913449107

Clausen, B. E., Burkhardt, C., Reith, W., Renkawitz, R., Forster, I. (1999). Conditional gene targeting in macrophages and granulocytes using LysMcre mice. Transgenic Res, 8, 265-277. https://doi.org/10.1023/a:1008942828960

Colonna, M. (2003). TREMs in the immune system and beyond. Nat Rev Immunol, 3, 445-453. https://doi.org/10.1038/nri1106

Davis, C. A., Vallota, E. H., Forristal, J. (1979). Serum complement levels in infancy: age related changes. Pediatr Res, 13, 1043-1046. https://doi.org/10.1203/00006450-197909000-00019

De Schepper, S., Stakenborg, N., Matteoli, G., Verheijden, S., Boeckxstaens, G. E. (2018). Muscularis macrophages: Key players in intestinal homeostasis and disease. Cell Immunol, 330, 142-150. https://doi.org/10.1016/j.cellimm.2017.12.009

De Schepper, S., Verheijden, S., Aguilera-Lizarraga, J., Viola, M. F., Boesmans, W., Stakenborg, N., Voytyuk, I., Schmidt, I., Boeckx, B., Dierckx de Casterle, I., Baekelandt, V., Gonzalez Dominguez, E., Mack, M., Depoortere, I., De Strooper, B., Sprangers, B., Himmelreich, U., Soenen, S., Guilliams, M., Vanden Berghe, P., Jones, E., Lambrechts, D., Boeckxstaens, G. (2018, Oct 4). Self-maintaining gut macrophages are essential for intestinal homeostasis. Cell, 175, 400-415 e413. https://doi.org/10.1016/j.cell.2018.07.048 
Earley, A.M., Graves, C.L., Shiau, C.E. (2018). Critical role for a subset of intestinal macrophages in shaping gut microbiota in adult zebrafish. Cell Rep, 25, 424-436. https://doi.org/ $\underline{10.1016 / \text { j.celrep.2018.09.025 }}$

Eichelberg, K., Galan, J. E. (1999). Differential regulation of Salmonella typhimurium type III secreted proteins by pathogenicity island 1 (SPI-1)-encoded transcriptional activators InvF and hilA. Infect Immun, 67, 4099-4105. https://doi.org/10.1128/IAI.67.8.4099-4105.1999

El-Shamy, A., Branch, A. D., Schiano, T. D., \& Gorevic, P. D. (2018). The complement system and C1q in chronic hepatitis $\mathrm{C}$ virus infection and mixed cryoglobulinemia. Front Immunol, 9, 1001. https://doi.org/10.3389/fimmu.2018.01001

Fawzy, M., Edrees, A., Okasha, H., El Ashmaui, A., Ragab, G. (2016). Gastrointestinal manifestations in systemic lupus erythematosus. Lupus, 25, 1456-1462. https://doi.org/10.1177/0961203316642308

Fonseca, M. I., Chu, S. H., Hernandez, M. X., Fang, M. J., Modarresi, L., Selvan, P., MacGregor, G. R., Tenner, A. J. (2017). Cell-specific deletion of C1qa identifies microglia as the dominant source of C1q in mouse brain. J Neuroinflammation, 14, 48. https://doi.org/10.1186/s12974-017-0814-9

Gabanyi, I., Muller, P. A., Feighery, L., Oliveira, T. Y., Costa-Pinto, F. A., Mucida, D. (2016). Neuroimmune interactions drive tissue programming in intestinal macrophages. Cell, 164, 378-391. https://doi.org/10.1016/j.cell.2015.12.023

Gattu, S., Bang, Y. J., Pendse, M., Dende, C., Chara, A. L., Harris, T. A., Wang, Y., Ruhn, K. A., Kuang, Z., Sockanathan, S., Hooper, L. V. (2019). Epithelial retinoic acid receptor beta regulates serum amyloid A expression and vitamin A-dependent intestinal immunity. Proc Natl Acad Sci U S A, 116, 10911-10916. https://doi.org/10.1073/pnas.1812069116

Grainger, J. R., Konkel, J. E., Zangerle-Murray, T., Shaw, T. N. (2017). Macrophages in gastrointestinal homeostasis and inflammation. Pflugers Arch, 469, 527-539. https://doi.org/10.1007/s00424-017-1958-2

Hammond, J. W., Bellizzi, M. J., Ware, C., Qiu, W. Q., Saminathan, P., Li, H., Luo, S., Ma, S. A., Li, Y., Gelbard, H. A. (2020). Complement-dependent synapse loss and microgliosis in a mouse model of multiple sclerosis. Brain Behav Immun, 87, 739-750. https://doi.org/10.1016/j.bbi.2020.03.004

Hong, S., Beja-Glasser, V. F., Nfonoyim, B. M., Frouin, A., Li, S., Ramakrishnan, S., Merry, K. M., Shi, Q., Rosenthal, A., Barres, B. A., Lemere, C. A., Selkoe, D. J., Stevens, B. (2016). Complement and microglia mediate early synapse loss in Alzheimer mouse models. Science, 352, 712-716. https://doi.org/10.1126/science.aad8373

Johnson, C.D., Barlow-Anacker, A.J., Pierre, J.F., Touw, K., Erickson, C.S., Furness, J.B., Epstein, M.L., Gosain, A. (2018). Deletion of choline acetyltransferase in enteric neurons results in postnatal intestinal dysmotility and dysbiosis. FASEB J, 32, 4744-4752. https://doi.org/10.1096/fj.201701474RR

Kishore, U., Reid, K. B. (2000). C1q: structure, function, and receptors. Immunopharmacology, 49, 159170. https://doi.org/10.1016/s0162-3109(00)80301-x 
Klindworth, A., Pruesse, E., Schweer, T., Peplies, J., Quast, C., Horn, M., Glockner, F. O. (2013). Evaluation of general 16S ribosomal RNA gene PCR primers for classical and next-generation sequencingbased diversity studies. Nucleic Acids Res, 41, e1. https://doi.org/10.1093/nar/gks808

Korb, L. C., Ahearn, J. M. (1997). C1q binds directly and specifically to surface blebs of apoptotic human keratinocytes: complement deficiency and systemic lupus erythematosus revisited. J Immunol, 158, 45254528. https://www.ncbi.nlm.nih.gov/pubmed/9144462

Kouser, L., Madhukaran, S. P., Shastri, A., Saraon, A., Ferluga, J., Al-Mozaini, M., Kishore, U. (2015). Emerging and novel functions of complement protein C1q. Front Immunol, 6, 317. https://doi.org/10.3389/fimmu.2015.00317

Kulkarni, S., Micci, M. A., Leser, J., Shin, C., Tang, S. C., Fu, Y. Y., Liu, L., Li, Q., Saha, M., Li, C., Enikolopov, G., Becker, L., Rakhilin, N., Anderson, M., Shen, X., Dong, X., Butte, M. J., Song, H., Southard-Smith, E. M., Kapur, R. P., Bogunovic, M., Pasricha, P. J. (2017). Adult enteric nervous system in health is maintained by a dynamic balance between neuronal apoptosis and neurogenesis. Proc Natl Acad Sci USA, 114, E3709-E3718. https://doi.org/10.1073/pnas.1619406114

Ling, G. S., Crawford, G., Buang, N., Bartok, I., Tian, K., Thielens, N. M., Bally, I., Harker, J. A., AshtonRickardt, P. G., Rutschmann, S., Strid, J., Botto, M. (2018). C1q restrains autoimmunity and viral infection by regulating CD8+ T cell metabolism. Science, 360, 558-563. https://doi.org/10.1126/science.aao4555

Luo, J., Qian, A., Oetjen, L. K., Yu, W., Yang, P., Feng, J., Xie, Z., Liu, S., Yin, S., Dryn, D., Cheng, J., Riehl, T. E., Zholos, A. V., Stenson, W. F., Kim, B. S., Hu, H. (2018,). TRPV4 channel signaling in macrophages promotes gastrointestinal motility via direct effects on smooth muscle cells. Immunity, 49, 107-119 e104. https://doi.org/10.1016/j.immuni.2018.04.021

Macedo, A. C., Isaac, L. (2016). Systemic lupus erythematosus and deficiencies of early components of the complement classical pathway. Front Immunol, 7, 55. https://doi.org/10.3389/fimmu.2016.00055

Mao, Y. L., Shen, C. L., Zhou, T., Ma, B. T., Tang, L. Y., Wu, W. T., Zhang, H. X., Lu, H. L., Xu, W. X., Wang, Z. G. (2017). Ablation of Tacr2 in mice leads to gastric emptying disturbance. Neurogastroenterol Motil, 29, e13117. https://doi.org/10.1111/nmo.13117

Matheis, F., Muller, P. A., Graves, C. L., Gabanyi, I., Kerner, Z. J., Costa-Borges, D., Ahrends, T., Rosenstiel, P., Mucida, D. (2020). Adrenergic signaling in muscularis macrophages limits infectioninduced neuronal loss. Cell, 180, 64-78 e16. https://doi.org/10.1016/j.cell.2019.12.002

Maurer, A. H. (2016). Gastrointestinal motility, part 2: small-bowel and colon transit. J Nucl Med Technol, 44, 12-18. https://doi.org/10.2967/jnumed.113.134551

Mortazavi, A., Williams, B. A., McCue, K., Schaeffer, L., Wold, B. (2008). Mapping and quantifying mammalian transcriptomes by RNA-Seq. Nat Methods, 5, 621-628. https://doi.org/10.1038/nmeth.1226

Muller, P. A., Koscso, B., Rajani, G. M., Stevanovic, K., Berres, M. L., Hashimoto, D., Mortha, A., Leboeuf, M., Li, X. M., Mucida, D., Stanley, E. R., Dahan, S., Margolis, K. G., Gershon, M. D., Merad, M., Bogunovic, M. (2014). Crosstalk between muscularis macrophages and enteric neurons regulates gastrointestinal motility. Cell, 158, 300-313. https://doi.org/10.1016/j.cell.2014.04.050 
881

882

883

884

885

886

887

888

889

890

891

892

893

894

895

896

897

898

899

900

901

902

903

904

905

906

907

908

909

910

911

912

913

914

915

916

917

918

919

920

921

922

923

924

925

926

927

928

Noris, M., Remuzzi, G. (2013). Overview of complement activation and regulation. Semin Nephrol, 33, 479-492. https://doi.org/10.1016/j.semnephrol.2013.08.001

Obata, Y., Castaño, A., Boeing, S., Bon-Frauches, A.C., Fung, C., Fallesen, T., de Agüero, M.G., Yilmaz, B., Lopes, R., Huseynova, A., Horswell, S., Maradana, M.R., Boesmans, W., Vanden Berghe, P., Murray, A.J., Stockinger, B., Macpherson, A.J., Pachnis, V. (2020). Neuronal programming by microbiota regulates intestinal physiology. Nature, 578, 284-289. https://doi.org/10.1038/s41586-020-1975-8

Paloneva, J., Manninen, T., Christman, G., Hovanes, K., Mandelin, J., Adolfsson, R., Bianchin, M., Bird, T., Miranda, R., Salmaggi, A., Tranebjaerg, L., Konttinen, Y., Peltonen, L. (2002). Mutations in two genes encoding different subunits of a receptor signaling complex result in an identical disease phenotype. Am J Hum Genet, 71, 656-662. https://doi.org/10.1086/342259

Petry, F., Botto, M., Holtappels, R., Walport, M. J., Loos, M. (2001). Reconstitution of the complement function in C1q-deficient (C1qa-/-) mice with wild-type bone marrow cells. J Immunol, 167, 4033-4037. https://doi.org/10.4049/jimmunol.167.7.4033

Rao, M., Gershon, M. D. (2016). The bowel and beyond: the enteric nervous system in neurological disorders. Nat Rev Gastroenterol Hepatol, 13, 517-528. https://doi.org/10.1038/nrgastro.2016.107

Rolig, A.S., Mittge, E.K., Ganz, J., Troll, J.V., Melancon, E., Wiles, T.J., Alligood, K., Stephens, W.Z., Eisen, J.S., Guillemin, K. (2017). The enteric nervous system promotes intestinal health by constraining microbiota composition. PLoS Biol, 15, e2000689. https://doi.org/10.1371/journal.pbio.2000689

Schifferli, J. A., Ng, Y. C., Peters, D. K. (1986). The role of complement and its receptor in the elimination of immune complexes. $N$ Engl J Med, 315, 488-495. https://doi.org/10.1056/NEJM198608213150805

Schwechter, B., Rosenmund, C., Tolias, K. F. (2013). RasGRF2 Rac-GEF activity couples NMDA receptor calcium flux to enhanced synaptic transmission. Proc Natl Acad Sci USA, 110, 14462-14467. https://doi.org/10.1073/pnas.1304340110

Shah, D., Romero, F., Zhu, Y., Duong, M., Sun, J., Walsh, K., Summer, R. (2015). C1q deficiency promotes pulmonary vascular inflammation and enhances the susceptibility of the lung endothelium to injury. $J$ Biol Chem, 290, 29642-29651. https://doi.org/10.1074/jbc.M115.690784

Thielens, N. M., Tedesco, F., Bohlson, S. S., Gaboriaud, C., Tenner, A. J. (2017). C1q: A fresh look upon an old molecule. Mol Immunol, 89, 73-83. https://doi.org/10.1016/j.molimm.2017.05.025

Tian, X. P., Zhang, X. (2010). Gastrointestinal involvement in systemic lupus erythematosus: insight into pathogenesis, diagnosis and treatment. World $J$ Gastroenterol, 16, 2971-2977. https://doi.org/10.3748/wig.v16.i24.2971

Ural, B. B., Yeung, S. T., Damani-Yokota, P., Devlin, J. C., de Vries, M., Vera-Licona, P., Samji, T., Sawai, C. M., Jang, G., Perez, O. A., Pham, Q., Maher, L., Loke, P., Dittmann, M., Reizis, B., Khanna, K. M. (2020). Identification of a nerve-associated, lung-resident interstitial macrophage subset with distinct localization and immunoregulatory properties. Sci Immunol, 5. https://doi.org/10.1126/sciimmunol.aax8756 
van Schaarenburg, R. A., Suurmond, J., Habets, K. L., Brouwer, M. C., Wouters, D., Kurreeman, F. A., Huizinga, T. W., Toes, R. E., Trouw, L. A. (2016). The production and secretion of complement component C1q by human mast cells. Mol Immunol, 78, 164-170. https://doi.org/10.1016/j.molimm.2016.09.001

Vrees, M. D., Pricolo, V. E., Potenti, F. M., Cao, W. (2002). Abnormal motility in patients with ulcerative colitis: the role of inflammatory cytokines. Arch Surg, 137, 439-445. https://doi.org/10.1001/archsurg.137.4.439

Warren, J., Mastroeni, P., Dougan, G., Noursadeghi, M., Cohen, J., Walport, M. J., Botto, M. (2002). Increased susceptibility of C1q-deficient mice to Salmonella enterica serovar Typhimurium infection. Infect Immun, 70, 551-557. https://doi.org/10.1128/IAI.70.2.551-557.2002

Wessels, M. R., Butko, P., Ma, M., Warren, H. B., Lage, A. L., Carroll, M. C. (1995). Studies of group B streptococcal infection in mice deficient in complement component $\mathrm{C} 3$ or $\mathrm{C} 4$ demonstrate an essential role for complement in both innate and acquired immunity. Proc Natl Acad Sci U S A, 92, 11490-11494. https://doi.org/10.1073/pnas.92.25.11490

Yang, C. H., Yeh, Y. J., Wang, J. Y., Liu, Y. W., Chen, Y. L., Cheng, H. W., Cheng, C. M., Chuang, Y. J., Yuh, C. H., Chen, Y. R. (2017). NEAP/DUSP26 suppresses receptor tyrosine kinases and regulates neuronal development in zebrafish. Sci Rep, 7, 5241. https://doi.org/10.1038/s41598-017-05584-7

Yu, X., Rollins, D., Ruhn, K. A., Stubblefield, J. J., Green, C. B., Kashiwada, M., Rothman, P. B., Takahashi, J. S., Hooper, L. V. (2013). TH17 cell differentiation is regulated by the circadian clock. Science, 342, 727-730. https://doi.org/10.1126/science.1243884

Yu, X., Wang, Y., Deng, M., Li, Y., Ruhn, K. A., Zhang, C. C., Hooper, L. V. (2014). The basic leucine zipper transcription factor NFIL3 directs the development of a common innate lymphoid cell precursor. Elife, 3, e04406. https://doi.org/10.7554/eLife.04406 


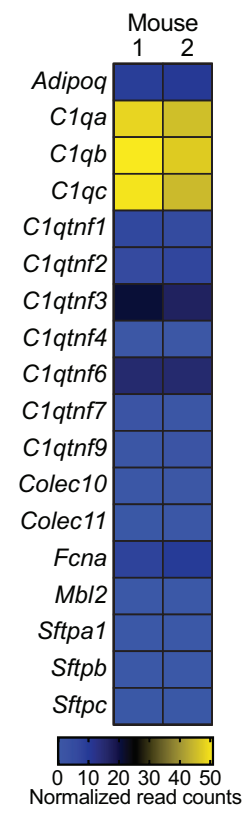

Figure 1 - figure supplement 1. C1q is expressed in the mouse colon.

RNA-seq analysis of soluble defense collagen expression in the colons of C57BL/6 mice. Data were reanalyzed from Gattu et al., 2019. Each column represents one mouse. Data are available in the Gene Expression Omnibus repository under accession number GSE122471. 
A

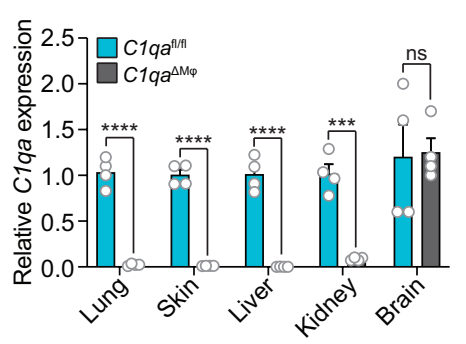

B

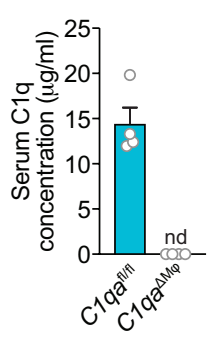

Figure 2 - figure supplement 1. C1q expression is lost systemically but preserved in the central nervous system of $\mathrm{Clqa}^{\Delta \mathrm{M} \varphi}$ mice.

(A) qPCR measurement of Clqa expression in lung, skin, liver, kidney, and brain. Each data point represents one mouse. Data are representative of two independent experiments.

(B) $\mathrm{C} 1 \mathrm{q}$ is absent from the serum of $\mathrm{Cl}_{q} \mathrm{a}^{\Delta \mathrm{M} \varphi}$ mice. Enzyme-linked immunosorbent assay (ELISA) detection of serum Clq protein from $C l q a^{\mathrm{fl} / \mathrm{fl}}$ and $C l q a^{\Delta \mathrm{M} \varphi}$ littermates. Data are presented as $\mathrm{Clq}$ serum concentration based on a standard curve generated from purified recombinant mouse C1q. Each data point represents one mouse. nd, not detected. Data are representative of three independent experiments.

Error bars represent SEM. ${ }^{* * *} \mathrm{p}<0.001 ; * * * * \mathrm{p}<0.0001 ; \mathrm{ns}$, not significant by two-tailed Student's t-test. 

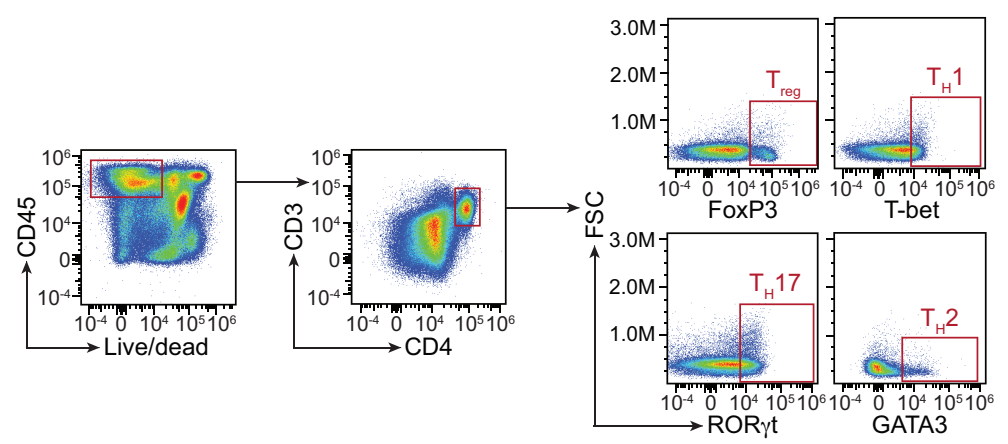

Figure 3 - figure supplement 1. Flow cytometry gating strategy for comparison of $\mathrm{T}$ cell populations in $C 1 q a^{\mathrm{t} / \mathrm{f}}$ and $C 1 q a^{\Delta \mathrm{M} \varphi}$ mice.

Small intestinal cells were recovered from $C 1 q a^{\mathrm{fl} / \mathrm{fl}}$ and $C 1 q a^{\Delta \mathrm{M} \varphi}$ littermates and analyzed by flow cytometry. T cells were gated as live $\mathrm{CD}_{4} 5^{+} \mathrm{CD}^{+} \mathrm{CD}^{+}$. $\mathrm{T}$ cell subsets were further identified by gating into $\mathrm{T}_{\text {reg }}\left(\mathrm{FoxP}^{+}\right), \mathrm{T}_{\mathrm{H}} 1$ ( $\mathrm{T}$ bet $\left.^{+}\right), \mathrm{T}_{\mathrm{H}} 17\left(\mathrm{ROR}_{\mathrm{rt}} \mathrm{t}^{+}\right)$, and $\mathrm{T}_{\mathrm{H}} 2\left(\mathrm{GATA}^{+}\right)$. Representative plots from $\mathrm{Clqa}^{\mathrm{t} / \mathrm{fl}}$ mice are presented and comparisons between $C l q a^{\mathrm{fl} / \mathrm{fl}}$ and $C l q a^{\mathrm{MM} \varphi}$ littermates are shown in Figure 3. FSC, forward scatter. 


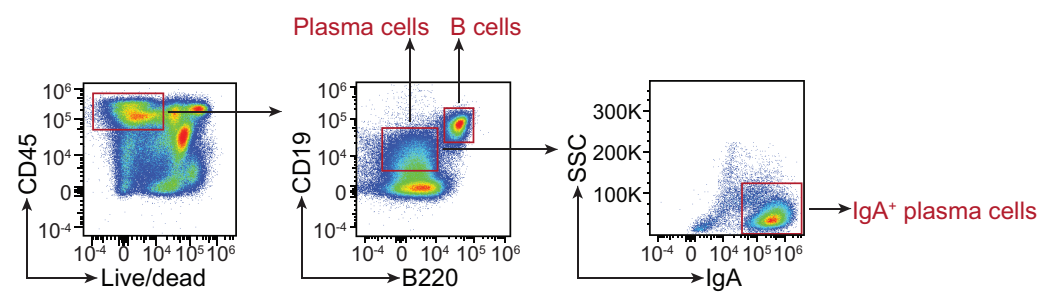

Figure 3 - figure supplement 2. Flow cytometry gating strategy for comparison of $B$ cell and plasma cell populations in $C 1 q a^{\mathrm{n} / 1 / 1}$ and $C 1 q a^{\Delta \mathrm{M} \varphi}$ mice.

Small intestinal cells were recovered from $C 1 q a^{\mathrm{fl} / \mathrm{fl}}$ and $C 1 q a^{\Delta \mathrm{M} \varphi}$ littermates and analyzed by flow cytometry. B cells were gated as live $\mathrm{CD} 45^{+} \mathrm{CD} 19^{+} \mathrm{B} 220^{+}$. Plasma cells were gated as $\mathrm{CD} 19^{+} \mathrm{B} 220^{-}$, and $\mathrm{IgA} \mathrm{A}^{+}$plasma cells were further identified. Representative plots from $C l q a^{\mathrm{fl} / \mathrm{fl}}$ mice are presented and comparisons between $C l q a^{\mathrm{fl} / \mathrm{fl}}$ and $C l q a^{\Delta \mathrm{M} \varphi}$ littermates are shown in Figure 3. SSC, side scatter. 


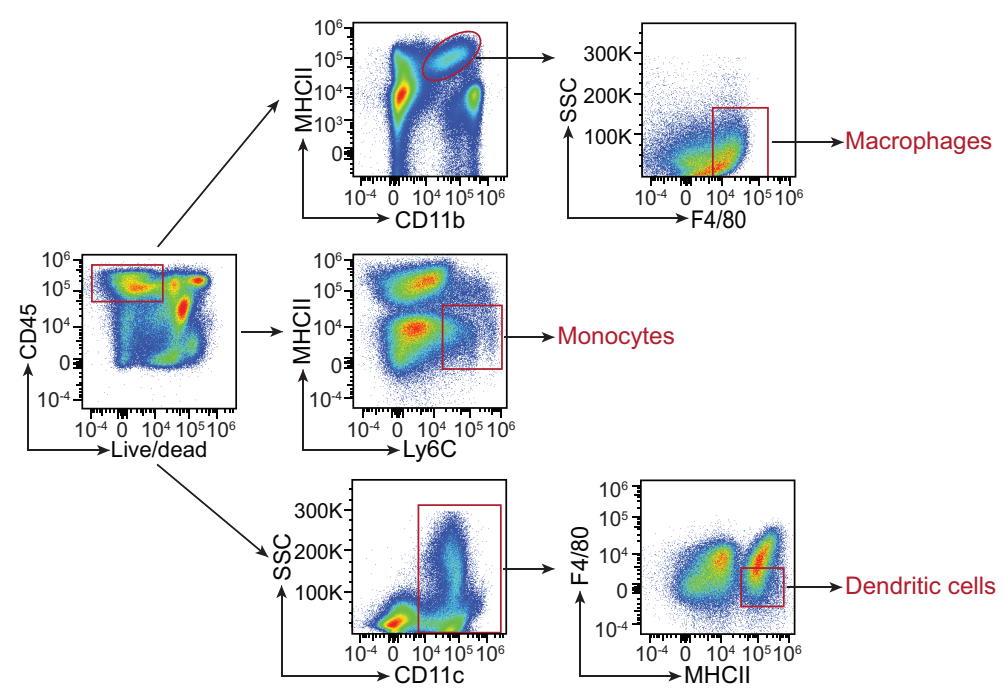

Figure 3 - figure supplement 3. Flow cytometry gating strategy for comparison of myeloid cell populations in $C 1 q a^{\mathrm{n} / \mathrm{fl}}$ and $\operatorname{Clqa}^{\Delta \mathrm{MM} \varphi}$ mice.

Small intestinal cells were recovered from $C l q a^{\mathrm{fl} / \mathrm{fl}}$ and $C l q a^{\mathrm{MM \varphi} \varphi}$ littermates and analyzed by flow cytometry. Macrophages were gated as live $\mathrm{CD}_{4} 5^{+} \mathrm{MHCII}^{+} \mathrm{CD} 11 \mathrm{~b}^{+} \mathrm{F} 4 / 80^{\text {hi }}$. Monocytes were gated as live $\mathrm{CD} 45^{+} \mathrm{MHCII}^{-}$ Ly6C ${ }^{+}$. Dendritic cells were gated as live $\mathrm{CD}_{4} 5^{+} \mathrm{CD} 11 \mathrm{c}^{+} \mathrm{MHCII}^{+} \mathrm{F} 4 / 80^{\mathrm{lo}}$. Representative plots from $\mathrm{Cl}$. $\mathrm{a}^{\mathrm{fl} / \mathrm{fl}}$ mice are presented and comparisons between $C l q a^{\mathrm{fl} / \mathrm{fl}}$ and $C l q a^{\Delta \mathrm{M} \varphi}$ littermates are shown in Figure 3. SSC, side scatter; MHCII, major histocompatibility complex II. 


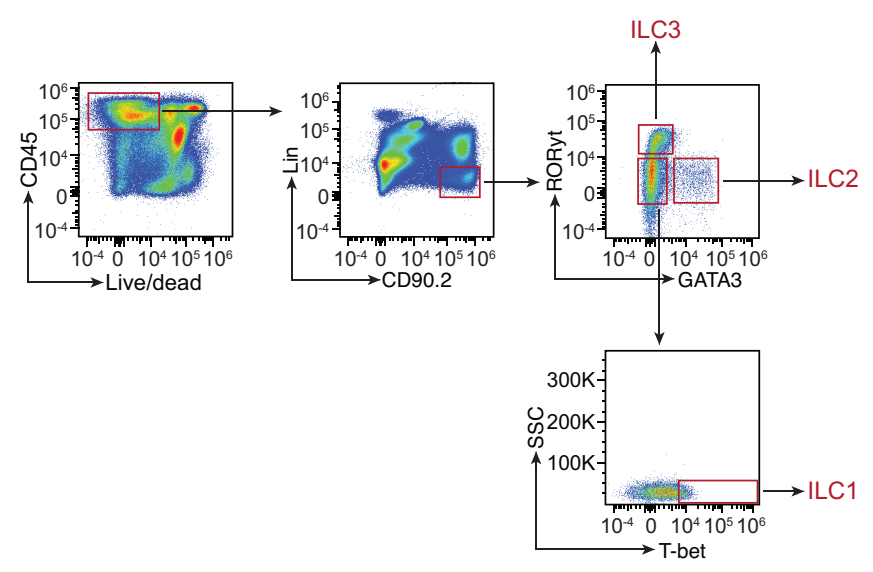

Figure 3 - figure supplement 4 . Flow cytometry gating strategy for comparison of innate lymphoid cell populations in $C 1 q a^{\mathrm{f} / 1 / 1}$ and $C 1 q a^{\Delta \mathrm{M} \varphi}$ mice.

Small intestinal cells were recovered from $C 1 q a^{\mathrm{fl} / \mathrm{fl}}$ and $C 1 q a^{\Delta \mathrm{M} \varphi}$ littermates and analyzed by flow cytometry. Innate lymphoid cells (ILC) were gated as live $\mathrm{CD} 45^{+} \mathrm{Lin}^{-} \mathrm{CD} 90.2^{+}$and then further identified as ILC1 (ROR $\gamma \mathrm{t}$ - GATA3T-bet $^{+}$), ILC2 (ROR $\gamma t^{-}$GATA3 ${ }^{+}$) and ILC3 (ROR $\gamma t^{+}$GATA3 $^{-}$). Representative plots from $\mathrm{Cl} q a^{\text {fl/fl }}$ mice are presented and comparisons between $C 1 q a^{\mathrm{fl} / \mathrm{fl}}$ and $C l q a^{\Delta \mathrm{M} \varphi}$ littermates are shown in Figure 3. SSC, side scatter. 


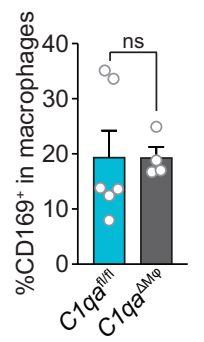

Figure 4 - figure supplement 1. Similar numbers of $\mathrm{CD169}^{+}$macrophages are present in the small intestines of $C 1 q a^{\Delta \mathrm{M} \varphi}$ and $C 1 q a^{\mathrm{f} / \mathrm{fl}}$ littermates.

Flow cytometry analysis of $\mathrm{CD} 169^{+}$macrophages was conducted on cells recovered from the small intestines of $C l q a^{\Delta \mathrm{M} \varphi}$ and $C l q a^{\mathrm{fl} / \mathrm{ll}}$ littermates. $\mathrm{CD} 169^{+}$cells were determined as a percentage of total macrophages (live CD45 $\mathrm{CD}_{11} \mathrm{~b}^{+} \mathrm{MHCII}^{+} \mathrm{F} 4 / 80^{\mathrm{hi}}$ cells). 


\section{(C1qa $\left.a^{\Delta M}: C 1 q^{a^{N / 4}}\right)$}

Figure 4 - figure supplement 2. The colonic longitudinal muscle myenteric plexus of $C_{1 q a^{\Delta M}}$ mice has a transcriptional profile similar to that of mice with a gastrointestinal motility disorder.

RNA-seq was performed on the colonic longitudinal muscle-myenteric plexus from five $C 1 q a^{\mathrm{fl} / \mathrm{fl}}$ and five $C 1 q a^{\Delta \mathrm{M} \varphi}$ littermates. Genes that were differentially expressed are represented in a heatmap that depicts $\log _{2}$ (fold change). Genes that also showed altered expression in the TashT mouse line, which is a model of human Hirschsprung's disease (Bergeron et al., 2015), are indicated in red. Statistical significance of overlap between differentially expressed genes in Clqa $a^{\Delta \mathrm{M} \varphi}$ and TashT mice was determined by Fisher's exact test $(\mathrm{p}=0.0032)$. 

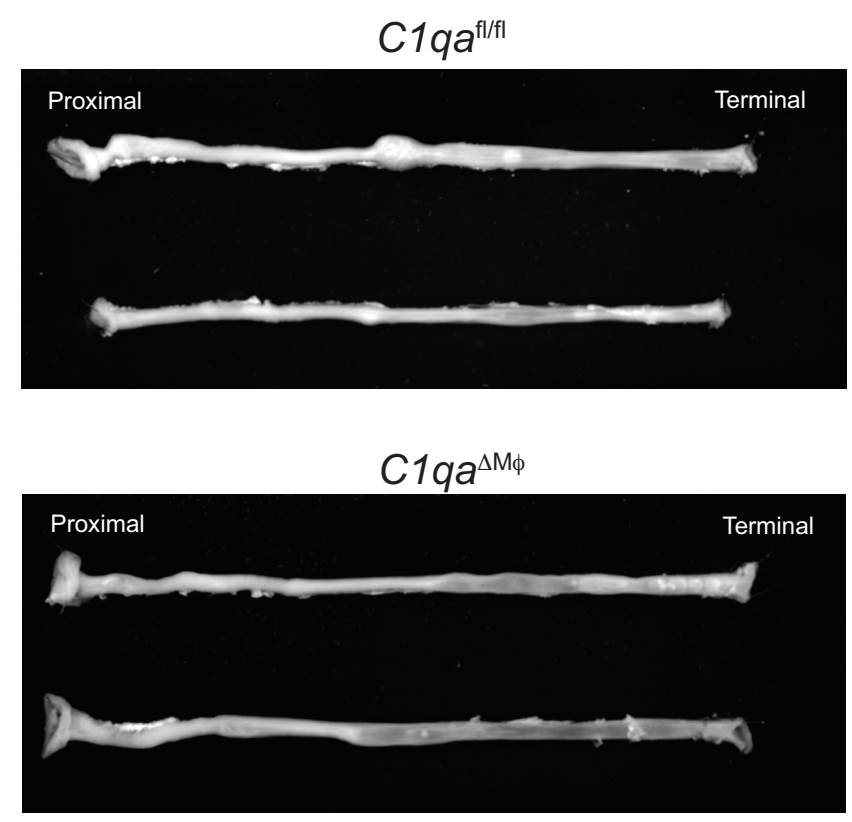

Figure 5 - figure supplements 1 and 2. Ex vivo video recordings of colonic peristalsis in $C 1 q a^{\mathrm{f} / 1 / 1}$ and $C 1 q a^{\Delta \mathrm{M} \varphi}$ littermates.

Still images captured from ex vivo video recordings of colonic peristalsis to indicate orientation of the colons. Colons were allowed to equilibrate to the organ chamber for 30 minutes before video recording. Movies were captured over 15 minutes. Colons from $C l q a^{\mathrm{fl} / \mathrm{fl}}$ mice are shown in figure supplement 1 ; colons from $C l q a^{\Delta \mathrm{M} \varphi}$ are shown in figure supplement 2. 